\title{
THE RELATIONSHIP BETWEEN GOVERNMENTS AND INDEPENDENT REGULATORY AGENCIES: WILL WE EVER GET IT RIGHT?
}

\author{
HUDSON JANISCH $^{*}$
}

This article examines the relationship that exists between governments and independent regulatory agencies. The article begins by reviewing this relationship within the context of the Usage Based Billing (UBB) debate that began after the Federal government, in opposition to a ruling by the Canadian Radio-television and Telecommunications Commission (CRTC), ordered the CRTC to go back and review its decision. After discussing the various arguments in favour of and against $U B B$, and discussing the policy concerns that exist with respect to government intervention in regulatory decisions, the article then provides a suggestion as to what should have occurred during the UBB debate. Next, the article looks at energy regulation at the provincial level, using Alberta and British Columbia as case studies. Finally, the article concludes with a discussion on potential regulatory structural reforms.
Cet article examine la relation entre les gouvernements et les organismes de réglementation indépendants. L'article commence par examiner cette relation dans le contexte du débat sur la facturation basée sur l'utilisation (Usage Based Billing (UBB)) qui a commencé après que le fédéral, s'opposant à décision du Conseil de la radiodiffusion et des télécommunications canadiennes (CRTC), ordonna celui-ci de revoir sa décision. Après avoir discuté les divers arguments en faveur et contre le UBB et après avoir discuté les inquiétudes sur la politique relative à l'intervention du gouvernement dans les décisions réglementaires, l'auteur suggère ce qui aurait dû se produire pendant le débat sur le UBB. Ensuite, l'article examine la réglementation en matière d'énergie sur le plan provincial en utilisant l'Alberta et la Colombie-Britannique comme étude de cas. Enfin, l'article se termine sur une discussion sur des réformes potentielles de la structure réglementaire.

\section{TABLE OF CONTENTS}

I. ACKNOWLEDGMENTS . . . . . . . . . . . . . . . . . . . . . . . . . . . 786

II. INTRODUCTION . . . . . . . . . . . . . . . . . . . . . . . . . . . . . . 786

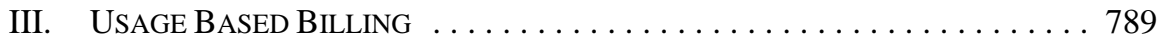

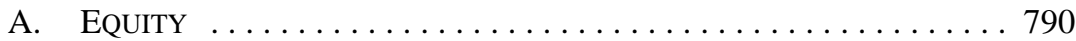

B. Cost Recovery . . . . . . . . . . . . . . . . . . . . . . . . . . 791

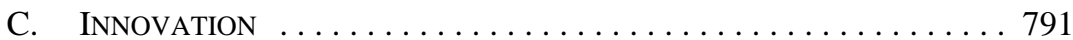

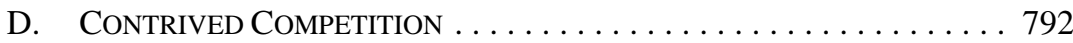

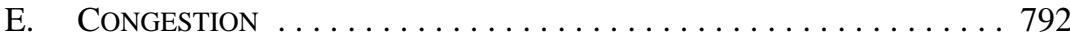

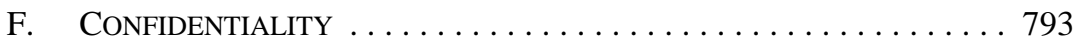

IV. From SubSTANTIVE TO PROCEDURAL CONCERNS . . . . . . . . . . . . . . . 794

V. INDEPENDENT REGULATORS: “STRUCTURAL HERETICS”? . . . . . . . . . . . 795

VI. USAge BASEd Billing: What ShOUld haVe Happened? . . . . . . . . . 799

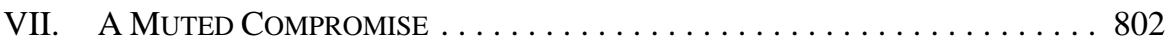

VIII. FOREIGN OWNERSHIP CONCERNS . . . . . . . . . . . . . . . . . . . . . . . . . . 804

IX. AsPECTS OF ENERGY REgUlAtion . . . . . . . . . . . . . . . . . . . . 806

X. INTERESTING TIMES IN BRITISH COLUMBiA . . . . . . . . . . . . . . . . 810

XI. Regulatory Structural ReForms in Alberta? . . . . . . . . . . . . 817

XII. CONCLUSION . . . . . . . . . . . . . . . . . . . . . . . . . . 820

Inaugural TransCanada Chair in Administrative and Regulatory Law, Faculty of Law, University of Alberta; Osler, Hoskin \& Harcourt Chair of Law and Technology Professor Emeritus, University of Toronto, Adjunct Professor, Faculty of Law, University of Victoria 2009-2011. This is a revised and updated version of a lecture given at the Energy Regulatory Forum, Calgary, Alberta, 10 May 2011. 


\section{ACKNOWLEDGMENTS}

I would like to start by thanking the Organizing Committee for their kind invitation to participate in the Energy Regulatory Forum. I am in Alberta as part of my most welcome responsibilities as the Inaugural TransCanada Chair in Administrative and Regulatory Law at the University of Alberta. I am most grateful to TransCanada for sponsoring the Chair, and to Dean Philip Bryden and his colleagues at the Faculty of Law for making my visits interesting and worthwhile.

\section{INTRODUCTION}

For someone who has been long involved in proposing improvements in the legal structure governing relations between governments and regulators, the spectacular debate in 2011 over Usage Based Billing (UBB) for Internet access came as a painful reminder that we have not yet devised a stable model for the relationship which should exist between governments and independent regulatory agencies — one that is capable of withstanding the shocks of politics.

What we saw was a complete disregard for the legal regime which had been put in place through the 1993 Telecommunications $A c t^{1}$ to govern the roles to be played by elected politicians in Cabinet (technically, Governor in Council) and the appointed bureaucrats in the regulatory agency - the Canadian Radio-television and Telecommunications Commission (CRTC). Briefly stated, the Act provides that the Cabinet, in response to a petition or on its own motion, may by order vary or rescind a CRTC decision, or refer it back for reconsideration. On receipt of a petition, the Minister of Industry has to publish notice of its receipt, consult with the provinces, and make the petition publically available. ${ }^{2}$ In a reference back, the Cabinet is required to set out details of any matter it considers material in the reconsideration, and should the Cabinet decide to vary or rescind a decision, it is required to set out its reasons for so doing. ${ }^{3}$ As it turned out, events were to make a mockery of this measured process.

On its face, the CRTC decision seemed innocuous enough. ${ }^{4}$ The decision provided that the wholesale UBB rates to be charged by the incumbents (the larger telecommunication and cable companies) to smaller Internet Service Providers (ISPs) should be established at a 15 percent discount from their UBB retail rates for Internet service. One might have thought that the ISPs and their customers would have welcomed the discount, but that would be to miss the real issue. This is because the smaller independent ISPs relied heavily on unlimited access as a marketing tool and were thus popular with heavy users who balked at the incumbents UBB plans. Understandably, the incumbents, whose facilities were already being used by the independent ISPs (who competed with them) at regulated rates, were concerned that they should not be able to offer flat rated, "all you can eat" access, when they themselves believed that they could not provide such service without causing network congestion and

CRTC, Usage-based billing for Gateway Access Services and third-party Internet access services (25 January 2011) Telecom Decision CRTC 2011-44, online: CRTC <http://www.crtc.gc.ca/eng/archive/ 2011/2011-44.htm> [CRTC, 2011-44]. 
depriving themselves of an adequate level of return on the massive investment they had made in network upgrades.

Through its decision, the CRTC had upset both the independent ISPs and their highly articulate customers, thereby causing something by way of a perfect political storm. It was to be the resultant public policy tsunami that threatened to swamp the good ship "Independent Regulator."

Less than a week after the release of the CRTC's decision, Minister of Industry Tony Clement (the Minister responsible for telecommunications at the Cabinet level at that time), acknowledged in an interview that the CRTC's decision had engendered a "strong reaction." 5 However, he adopted a calm and measured response in keeping with the legal parameters within which he operated. He said that he would study the decision to see how it squared with his government's commitment to encourage competition and consumer choice in the telecommunications industry. He added that he would be making a recommendation to his Cabinet colleagues on how they should proceed. It was reported that he was careful not to take sides, but said that it was incumbent on the government to determine whether the decision might make Canada less competitive in an Internet age. ${ }^{6}$ So far, so good.

A day later, Prime Minister Stephen Harper joined Minister Clement in calling for a review. ${ }^{7}$ By then a petition had been lodged with the Cabinet by a Montreal consultant who had participated in the CRTC decision, and it was noted that this gave the campaign against the decision "a jolt of legitimacy." ${ }^{\circ}$ However, it was to be the fecundity of an online campaign orchestrated by OpenMedia.ca, a public interest lobby group initially organized in connection with an earlier "net neutrality" debate, which gave the uprising the sort of legitimacy that really counted in what was already widely perceived as an election year. ${ }^{9}$ What had so quickly escalated into a massive consumer backlash caught the attention of all political parties in Ottawa and the CRTC Chairman, Konrad von Finckenstein, was summoned to appear before the House of Commons Standing Committee on Industry, Science, and Technology. ${ }^{10}$

Steven Chase \& Iain Marlow, “Ottawa enters dispute over higher Internet fees,” The Globe and Mail (31 January 2011), online: The Globe and Mail <http://www.theglobeandmail.com/news/technology/ tech-news/ubb-internet/ottawa-enters-dispute-over-higher-internet-fees/article1889321/> [Chase \& Marlow, "Ottawa enters dispute"].

Ibid.

Steven Chase \& Iain Marlow, “Harper steps into Web dispute,” The Globe and Mail (1 February 2011), online: The Globe and Mail <http://www.theglobeandmail.com/technology/tech-news/harper-steps-intoweb-dispute/article565219/> [Chase \& Marlow, "Harper”].

$8 \quad$ Ibid.

9 Iain Marlow, “Regulator tightens rules on unlimited Web use,” The Globe and Mail (26 January 2011) online: Globe Advisor <https://secure.globeadvisor.com/servlet/ArticleNews/story/gam/20110126/ RB CRTCUBBMARLOWATL $>$. Within a day of the CRTC's decision, OpenMedia.ca claimed to have more than 40,000 signatures on an online petition condemning the decision. Within a week, OpenMedia.ca's “Stop The Meter” online petition had 300,000 signatures. See Chase \& Marlow, "Harper," supra note 7. Although only a very small number of Internet users would have been affected by the decision, nonetheless "a powerful grassroots campaign against the ruling [formed, being] so fierce it threatened to become a major political controversy ahead of a possible federal election [in the] spring”: Steven Chase, "Tories side with consumers in clash over Internet billing,” The Globe and Mail (3 February 2011), online: The Globe and Mail < http://www.theglobeandmail.com/technology/tech-news/ politics/tories-side-with-consumers-in-clash-over-internet-billing/article565474/> [Chase, "Tories side"]. Iain Marlow, "CRTC head called before committee over usage-based billing," The Globe and Mail (2 February 2011), online: The Globe and Mail <http://www.theglobeandmail.com/technology/technews/crtc-head-called-before-committee-over-usae-based-billing/article565221/>. 
By this time Minister Clement had changed his tune and his tone. He now indicated, in response to a question as to what his government was going to do, that the CRTC had to "go back to [the] drawing board."11 On the eve of Chairman von Finckenstein's appearance before the Parliamentary Committee, Minister Clement added additional pressure by indicating that he would be closely scrutinizing what the Chairman had to say in defence of the decision. ${ }^{12}$ In the end, the regulator capitulated. After making a short justification of the decision, von Finckenstein announced that the CRTC would "of its own motion" launch a review of the impugned decision. In doing so, von Finckenstein said that the CRTC was acting in response to "evident concerns expressed by Canadians." 13 It was clear that he was seeking to save a scrap of dignity and respect for institutional autonomy, but Minister Clement would have none of it. Although the CRTC only agreed to a reconsideration of its decision, in insisting that the regulator had to come up with an entirely new and different decision, the Minister acted as if the decision had been rescinded. "I'd like to be clear," Minister Clement told reporters, "regardless of the outcome of the CRTC review, under a Conservative government, this ruling will not be implemented."14

Overall, what happened reminded me of an addendum to the rules of the first open boomerang tournament: "Decisions of the judges will be final unless shouted down by a really overwhelming majority of the crowd present." 15 In an electronic age, crowds can readily be made to appear to be present with their shouts captured on online petitions. Indeed, electronic gadgetry played a prominent role in the whole UBB regulatory ordeal.

Minister Clement is a proud and prolific tweeter. Indeed, his metamorphoses from responsible caution to impetuous over-intervention was driven by electronic gadgetry. Here the medium was indeed the message! As noted by Richard French, a former Vice Chairman (Telecommunications) at the CRTC, the Tories seemed determined to sideline normal deliberative due process in making decisions: "This is government by tweet, and amateur night at the Industry Department."16

Minister Clement remained unrepentant in his enthusiasm for Twitter. Mark Garneau, the Liberal telecommunications critic, inquired: “Are we, in fact, setting government policy and government decisions by means of 140 characters that you send out in the middle of the night to tell the CRTC, a respected regulatory body, how decisions are [to be] made in this country?”"17 To which Minister Clement replied: “There is nothing different from articulating government policy via social media as compared to a news release, or a press conference or

Steven Chase, "Government policy decisions, in 140 characters or less," The Globe and Mail (3 February 2011), online: The Globe and Mail <http://www.theglobeandmail.com/news/politics/ government-policy-decisions-in-140-characters-or-less/article1893830/> [Chase, "Government”]. CRTC, Review of billing practices for wholesale residential high-speed access services (8 February 2011), Telecom Notice of Consultation CRTC 2011-77, online: CRTC <http:/www.crtc.gc.ca/eng/ archive/2011/2011-77.htm> [CRTC, 2011-77].

13 See Chase, “Tories side," supra note 9.

14 Ibid [emphasis added].

15 Mudgeeraba Creek Emu-Riding and Boomerang-Throwing Association, "Decisions of the Judges Will be Final Unless Shouted Down By a Really Over-Whelming Majority of the Crowd Present,” online: Anvari.org <http://www.anvari.org/fortune/Miscellaneous_Collections/380772_decisions-of-the-judgeswill-be-final-unless-shouted-down-by-a-really-overwhelming-majority-of-the-crowd-present.html $>$. Chase, “Government," supra note 11.

"Don’t fear the tweeter, Clement says in defending policy via social media,” The Globe and Mail (1 March 2011), online: The Globe and Mail <http://www.theglobeandmail.com/news/technology/technews/dont-fear-the-tweeter-clement-says-in-defending-policy-via-social-media/article1925707/>. 
other means that have been traditionally available to politicians." ${ }^{\text {"18 }}$ While well outside the ambit of my topic, it would be interesting to consider the implications for policy-making that this new ability to broadcast instant decisions - without an opportunity to think things over - as compared to composing, for example, a traditional press release. Act in haste, the old adage goes, and repent at leisure.

I have to wonder if the Minister, (whom I had as a student in administrative law at the University of Toronto), has ever checked out the origins of the name "Twitter." The creator, Jack Dorsey, says that he chose the name after learning that the definition of "twitter" was "a short burst of inconsequential information." 19

\section{USAGE BASED BILLING}

As my concern here is essentially with regulatory process issues (who should decide what, and with what degree of finality?) this is not a suitable occasion on which to deal at length with the substantive policy issues involved in UBB. Nevertheless, it is always helpful to have at least some understanding of the underlying questions under consideration in thinking about appropriate institutions for decision-making. So, let me provide a flavour of the arguments as they emerged at the time in the context of Internet access, set against a background of telecommunications evolution.

There had long been a debate within the telecommunications industry as to the role UBB should play. For instance, in the mid-1970s, Ed Graham, Vice-President (Planning) at the New Brunswick Telephone Company Ltd, acknowledged at a conference at Dalhousie University that there were two extreme views about measuring: "Go measured or go broke," or "Go measured and go broke.” 20 "I am sure,” he added, “certainly within my own company, and I would guess within this audience, there are proponents of both of these slogans."21 The compromise arrived at for traditional voice telephony was to have flat rates for local service and usage-based rates for long distance. ${ }^{22}$ Starting in 2006, most Internet access has been provided on a measured basis with what initially seemed to be generous caps. This meant that the overwhelming majority of subscribers stayed within the monthly basic service charge. ${ }^{23}$ This, in turn, led to a widespread assumption that Internet access was being provided on a

18 Ibid.

David Sarno, “Twitter creator Jack Dorsey illuminates the site’s founding document. Part I,” Los Angeles Times (18 February 2009), online: LA Times <http://latimesblogs.latimes.com/technology/ 2009/02/ twitter-creator.html>.

20 HN Janisch, ed, Telecommunications Regulation at the Crossroads (Halifax: Dalhousie Continuing Legal Education Series, No 13, 1976) at 129.

Ibid.

22 For a valuable account of proposals (never adopted in Canada) to move to local measured service, see Richard J Schultz \& Peter Barnes, eds, Local Telephone Pricing: Is There a Better Way? (Montreal: The Centre for the Study of Regulated Industries, McGill University, 1984).

23 Iain Marlow, "Why not a metered Internet?,” The Globe and Mail (7 February 2011), online: The Globe and Mail <http://www.theglobeandmail.com/news/technology/tech-news/why-not-a-metered-internet/ article565334/> [Marlow, "Metered Internet”]. 
flat rate basis. ${ }^{24}$ Only after the CRTC's decision with respect to the rates cable and telecommunication companies could charge independent ISPs for using their networks (which would have ensured that they would also have to place usage caps on their services) did a highly articulate group of technologically sophisticated heavy users lead the protest against the "metering" of the Internet.

It is possible to tease out six principal concerns from the wild fracas which followed.

\section{A. EQUITY}

Would it not make sense to charge for Internet access on a usage basis, as is done for electricity and gas? ${ }^{25}$ As pointed out by Leonard Waverman, Dean of the Haskayne School of Business, University of Calgary, and a leading telecommunications industry economist:

The federal government has Twittered itself into a dilemma. By announcing support for unmetered broadband, it has driven Canada into an unfortunate corner. Telecom investment will be constrained because of the inability of suppliers, who own the cables and airwaves, to charge adequately the 20 per cent of Internet customers who use up 80 per cent of total bandwidth capacity. And the 80 per cent of us who seldom download movies will subsidize the 20 per cent who have the heaviest use of Internet traffic. ${ }^{26}$

This was, essentially, the CRTC's defence as well. Even as it backed down and agreed to review its decision, Chairman von Finckenstein made a strong justification in his appearance before the House of Commons Standing Committee:

I would like to reiterate the Commission's view that usage-based billing is a legitimate principle for pricing Internet services. We are convinced that Internet services are no different than other public utilities, and the vast majority of Internet users should not be asked to subsidize a small minority of heavy users. For us, it is a question of fundamental fairness. Let me restate: ordinary users should not be forced to subsidize heavy users. $^{27}$

This concern was to be carried over into the terms of review of the CRTC's decision, one of whose "fundamental principles" provided that "as a general rule, ordinary consumers served by small Internet Service Providers (ISPs) should not have to fund the bandwidth used by the heaviest retail Internet service consumers.”28 Significantly, Minister Clement had

Jane Taber, “Majority scoffs at usage-based Internet billing in poll,” The Globe and Mail (7 February 2011), online: The Globe and Mail <http://www.theglobeandmail.com/news/politics/ottawa-notebook/ majority-scoffs-at-usage-based-internet-billing-in-poll/article1897555/>. The Angus Reid Vice-President in charge of the poll, Jaideep Mukerji, said at the time, "I think Canadians see the Internet a bit like television: You pay for cable, and perhaps pay more for extra bells and whistles, but the amount of television you watch, or the amount of information you download from the Internet, shouldn't necessarily factor into how much you pay" (ibid).

25 Marlow, "Metered Internet," supra note 23.

26 Leonard Waverman, "Make the heaviest online users pay their fair share," The Globe and Mail (7 February 2011), online: The Globe and Mail < http://www.theglobeandmail.com/technology/tech-news/ make-the-heaviest-online-users-pay-their-fair-share/article565445/>.

27 CRTC, News Release, "Statement from the Chairman of the CRTC on usage-based billing” (3 February 2011), online: CRTC < http://www.crtc.gc.ca/eng/com100/2011/i110203.htm> [CRTC, "New Release”]. CRTC, 2011-77, supra note 12. 
sought to undercut this assumption to be employed in the review by saying that he did not believe that there was any proof of a link between heavy and ordinary Internet users. ${ }^{29}$

\section{B. COST RECOVERY}

Critics of any further move towards UBB were quick to point out that while the "cost" to transport a gigabyte might be less than one penny, Bell Canada charged between $\$ 1.50$ and $\$ 2.50$ for each gigabyte over the monthly cap in its subscriber plans. ${ }^{30}$ This, of course, is to ignore the substantial cost of putting broadband facilities in place, and the subsequent cost involved in upgrading the network and extending it ever more widely. As Mirko Bibic, Senior Vice-President for Regulatory and Governmental Affairs at Bell Canada (and a former student of administrative law at the University of Toronto) put it when explaining why independent ISPs might be able to offer unlimited downloads: "When you invest zero, yeah, it's pretty easy to say the cost-per-gig or per-bit is small. But when you invest billions, you've got to generate a return."31

\section{INNOVATION}

There were concerns that limits on downloading would inhibit the growth of innovative Internet services. The Globe and Mail ran a story, said to reflect the sort of worry businesses would now face. A developer of sophisticated, highly-interactive websites had come up with a site, rich in video features, designed to explain to the public the benefits of a huge proposed infrastructure project:

The discussions kept getting derailed by the same concern. In Canada, many Internet customers have strict limits on the amount of data they can download and upload. If they go over those limits, Internet providers such as BCE Inc.'s Bell Canada unit and Rogers Communications Inc., charge them extra fees. Would this website actually use up too much of the Internet?

\footnotetext{
"The client was producing a big, beautiful, heavily produced video that they wanted to present in the best possible format. They had spent a fortune on producing this,” said Ms. Morton, who co-owns Peapod Studios in Hamilton, Ont. "They were very concerned about doing it, mostly because of the cost to end users - the cost to deliver it." 32
}

As Minister Clement succinctly put it: ““‘ $[\mathrm{M}]$ any new and innovative businesses’ depended on fair and affordable Internet access.”33

Howard Solomon, "Clement undercuts defence of usage-based billing,” it World Canada (2 March 2011), online: it World Canada <http://www.itworldcanada.com/news/clement-undercuts-defence-ofusage-based-billing/142632> [Solomon, "Clement undercuts defence”].

Marlow, "Metered Internet,” supra note 23.

Chase \& Marlow, "Harper," supra note 7.

Iain Marlow, “Internet usage caps draw the ire of business,” The Globe and Mail (28 January 2011), online: The Globe and Mail <http://www.theglobeandmail.com/technology/tech-news/internet-usagecaps-draw-ire-of-business/article565216/>.

33 "Internet ruling could choke innovation - Canada," Reuters (1 March 2011), online: Reuters < http:// reuters.com/article/2011/03/01/canada-internet-idUSN0115399420110301> [Reuters]. 


\section{CONTRIVED COMPETITION}

Independent ISPs are seen as providing critically important competition through the provision of innovative Internet services. However, they are also economically fragile, and dependent on benign support from the regulator to give them preferred access to cable and telecommunication networks. They are, as The Globe and Mail recognized, "wards of the state," 34 and entirely dependent on the regulator. Thus, any decision which would deprive them of their trump card — unlimited access — would likely be seen as reducing essential competition. As Minister Clement observed: "Without the right competitive pressures, usagebased billing threatens to choke off these types of innovative businesses and the benefits they can bring to Canadian consumers and Canada's digital economy." 35 And: "If you want choice and competition you can't force down the throats of the independent ISPs a business model that means that they can't compete." ${ }^{\text {,6 }}$

It should be noted that the second of the fundamental principles adopted by the CRTC in the review of its initial decision was that "smaller ISPs should continue to be in a position to offer competitive and innovative alternatives." ${ }^{37}$

\section{E. CONGESTION}

The larger ISPs contended that they had to resort to UBB to cope with network congestion. For instance, Bell Canada argued that as Internet traffic increases in an era of online video services such as Netflix, the company needs to charge its wholesale (ISP) clients in a manner similar to its own retail customers - on a per-byte model that encourages consumers to think about what they choose to download or watch online. This was met with some skepticism at the CRTC review hearings: "Len Katz, the CRTC's vice-chair for telecommunications, said Bell frequently talks about how explosive Internet traffic is leading to congestion on the company's network. 'Yet, when I took a look at your forecast over the next five years, (Internet traffic) growth seems to have curtailed.... Am I missing something here?'”38

Minister Clement had been similarly skeptical when Bell Canada had suggested earlier that a minority of "heavy users" would slow down the network for others. "I've seen no evidence of that," Clement countered, “[t]here's no evidence that there is congestion as a result of any of that, and there's no evidence that the pricing structure of UBB in the retail market is the solution if congestion did exist." 39 He noted that the type of UBB adopted was

“Usage-based billing. And cooing,” Editorial, The Globe and Mail (2 February 2011), online: The Globe and Mail <http://www.theglobeandmail.com/news/opinions/editorials/usage-based-billing-and-cooing/ article1892324/> ["UBB Cooing”]. For all the CRTC's faith that the independent ISPs will bring pricing discipline, innovation, and consumer choice, it should be borne in mind that they only have a 6 percent market share: see CRTC, News Release, "CRTC report shows more Canadians are adopting broadband Internet and wireless services” (July 2011), online: CRTC < http://crtc.gc.ca/eng/com100/2011/ r110728.htm>.

Reuters, supra note 33.

Solomon, "Clement undercuts defence," supra note 29.

CRTC, 2011-77, supra note 12.

Iain Marlow, "BCE put on hot seat at hearing on Web pricing,” The Globe and Mail (11 July 2011), online: The Globe and Mail <http://www.theglobeandmail.com/news/technology/tech-news/bce-put-onhot-seat-at-hearing-on-web-pricing/article2093320/>. 
not linked to time of day pricing, even though Bell Canada had said that peak viewing hours were a particular problem: “No one’s saying there's congestion at 3 a.m.... There's no correlation on the retail side to fix that problem, if there's a problem.... That's where I get my dander up." 40

\section{F. CONFIDENTIALITY}

In a striking example of how substantive and procedural issues can overlap, critics claimed that the CRTC was too close and dependent on the industry it regulated, in part because it was not prepared to reveal corporate information it had on file. This, David Beers, Editor of The Tyee claimed, would have revealed just how much Internet users should be charged: "Sadly, as we've learned, the CRTC itself can only base its decisions on cost estimates provided by the big telecoms, because there is so little independent auditing in this area. We won't know until what a Globe and Mail editorial called the "black box" of Internet infrastructure costs is opened to public view." ${ }^{41}$

In its editorial, The Globe and Mail had lamented that unlike in other utilities, the commodity price per unit of Internet access was not publicly known.

But the actual cost to ISPs of downloading a lot of data is a black box; while large providers on occasion file information in confidence to the CRTC, the public has little ability to assess their claims around whether, say, \$1 per gigabyte (equivalent to around an hour of online video) for heavy users is justifiable. The large ISPs argue that this is acceptable, because we have a competitive marketplace. ${ }^{42}$

In an era of competitive telecommunications, the last thing the CRTC would want is to get drawn into setting retail Internet access rates based on some concept of "actual cost.” This would require the CRTC to undertake a massive costing exercise which simply does not exist, yet critics continue to assume the information is being kept from them. Such an expensive undertaking might be justified when there is a monopoly, but not where there is competition to provide Internet services. With this in mind, the CRTC has strongly resisted calls for its review to include retail rate-setting and broader issues, and has insisted that the exclusive focus of its review be on the wholesale rates telecommunication and cable companies charge independent ISPs. As it announced on 11 March 2011:

The CRTC will not be expanding the scope, as requested by several parties, to include the billing practices for retail Internet services. There is no evidence that market forces are not working properly in this unregulated market.

Finally, the CRTC will not review, as was also requested by several parties, the overall regulatory framework for wholesale high-speed Internet access services. The overall framework was not part of the decision that

$40 \quad$ Ibid.

$41 \quad$ David Beers, "The public is right to be cynical of Internet usage regulators,” The Globe and Mail (7 February 2011), online: The Globe and Mail <http://www.theglobeandmail.com/technology/tech-news/ the-public-is-right-to-be-cynical-of-internet-usage-regulators/article565449/>. 
is being reviewed, and it would not be appropriate to initiate such a wide-ranging review within the current proceeding. $^{43}$

\section{From Substantive to Procedural Concerns}

For a regulatory lawyer, what is particularly fascinating about the UBB row was that it was soon seen as raising significant procedural issues: "What began with a simple Twitter post by Industry Minister Tony Clement ... [where] he pledged to block a ruling on Internet pricing by the [CRTC] ... morphed into a controversy over the independence and future of the regulator." 44 This concern built on a number of interventions since 2006 by the government designed to push the regulator towards more pro-competitive rulings and to increase competition through more foreign investment in the telecommunications industry. This policy push will be highlighted in the next section. What needs to be emphasized here is the extent of the confusion and uncertainty which had resulted from the tweets of Prime Minister Harper and Minister Clement which ignored the procedures set out in the Telecommunications Act. "When it comes to politics, there are no rules for this industry, they'll be made up on the fly,"45 said Michael Hennessy, Senior Vice-President for Regulatory and Governmental Affairs at Telus. He then added a note of resignation, "[t]hat's unfortunate, but that's the way it seems to be." ${ }^{46}$

Richard French, a former Vice-Chairman at the CRTC from 2005-2007 and now CNTellier Professor at the University of Ottawa’s Graduate School of Public and International Affairs, identified the inevitable consequences of politicized regulation:

The more the government reflexively reacts to public pressure by stepping in to placate the disappointed, the more it incents future stakeholders to induce such pressure, thus establishing a political dynamic that will feed on itself.

We established independent regulators because they're supposed to have the expertise, the freedom from partisan pressures, the time and the longer-term perspective to make the painful and complex decisions required to keep industries that are otherwise liable to market failure operating in some semblance of the public interest. Does the cabinet really want to position itself as the effective arbiter for all the campaigns of rent-seeking and special pleading that an institution such as the CRTC has historically dealt with? ${ }^{47}$

It is now time for us to step back from these immediate issues to identify why it is that government-regulator relations have at times been so unstable. This will require us to consider some constitutional foundations.

CRTC, News Release, “CRTC to hold public hearings on wholesale Internet access services” (11 March 2011), online: CRTC <http://crtc.gc.ca/eng/com100/2011/r110311.htm>.

Iain Marlow \& Susan Krashinsky, “Telecoms face new uncertainty,” The Globe and Mail (3 February 2011), online: The Globe and Mail <http://www.theglobeandmail.com/news/technology/tech-news/ubbinternet/telecoms-face-new-uncertainty/article1893776/>.

Ibid.

Ibid.

Richard French, "Second-guessing the CRTC comes at a price,” The Globe and Mail (2 February 2011), online: The Globe and Mail <http://www.theglobeandmail.com/technology/tech-news/opinions/opinion/ second-guessing -the-crtc-comes-at-a-price/article565220/> [French, "Second-guessing”]. 


\section{INDEPENDENT REGULATORS: “STRUCTURAL HERETICS”?}

As I initially suggested, the UBB regulatory debate does not represent by any means the first breakdown in orderly government-regulator relations. Why has this been so? I would suggest that we need always bear in mind how difficult it is to fit "independent" regulatory agencies into our vertical, hierarchical, Westminster form of parliamentary government. Briefly put, they just do not fit easily into our scheme of ministerial accountability. Indeed, in our system of government, such agencies may, as JE Hodgetts (a Professor of political science at the University of Toronto, widely considered to be the father of public administration studies in Canada) insisted, be nothing less than "structural heretics." 48 The true home of independent regulatory agencies has always been in the US with its constitution being based on a more compatible separation of powers doctrine. However, even there, there have been grumblings, from time to time, about a "headless fourth branch of government."49

As the Economic Council of Canada put it in 1979, rather than place regulatory power in the hands of fully-fledged independent agencies, as has been done in many instances in the US, Canada has chosen a "halfway position" between the independence characteristic of the US and the accountability characteristic of the UK. ${ }^{50}$ Day-to-day regulation by statutory agencies, the Council continued, requires full-time detached professionalism that can only be obtained by giving such bodies a considerable degree of autonomy. ${ }^{51}$ At the same time, governments have not been willing to see final decision-making authority handed over to non-elected bodies. This has led to Cabinet review and appeal provisions, which have been used, albeit, somewhat sparingly. ${ }^{52}$

This, then, is the little understood Canadian compromise between regulatory independence and political control, the source of so much tension and confusion. I believe that concern for accountability has been overstated, as even in a parliamentary system of government, regulatory processes can be achieved by means other than direct political control. As Margot Priest, Partner in the Regulatory Consulting Group Inc of Ottawa, observed with respect to administrative tribunals more generally, their open processes and structures may well overcome their alleged anomalous creation. ${ }^{53}$ This possibility of transparent, process legitimacy led me to champion independent regulatory agencies in an article provocatively and accurately subtitled: "In Praise of Structural Heretics."

In 1992, I had the good fortune to act as counsel to the Senate Standing Committee (Senate Committee) on Transportation and Communications, chaired by Senator Donnie Oliver of Nova Scotia, in its detailed "pre-study” of Bill C-62 (which eventually became the

48 JE Hodgetts, The Canadian Public Service: A Physiology of Government 1867-1970 (Toronto: University of Toronto Press, 1973) at 138-56.

HN Janisch, “Policy Making in Regulation: Towards a New Definition of the Status of Independent Regulatory Agencies in Canada” (1979) 17 Osgoode Hall LJ 46 at 56-61.

Responsible Regulation: An Interim Report by the Economic Council of Canada (Hull, Que: Supply and Services Canada, 1979) at 53-68 [Responsible Regulation].

Ibid.

Ibid.

See Margot Priest, "Structure and Accountability of Administrative Agencies” in Law Society of Upper Canada, ed, Special Lectures of the Law Society of Upper Canada, Administrative Law: Principles, Practice and Pluralism (Scarborough: Carswell, 1992) 11.

54 HN Janisch, “Independence of Administrative Tribunals: In Praise of 'Structural Heretics”” (1988) 1:1 Can J Admin L \& Prac 1 [Janisch, "Heretics”]. 
1993 Telecommunications Act). In a pre-study, legislation is introduced in the House of Commons, and on being given first reading, is then referred to the Senate for examination in a relatively non-partisan environment. The Senate Committee was able to bring about a number of improvements in the bill which were later adopted in the House of Commons and incorporated into the final legislation. ${ }^{55}$ Most importantly for our purposes, the Senate Committee rejected the notion of a highly discretionary ministerial licencing regime favoured by officials at the Department of Communications in favour of open and transparent regulation by an independent regulatory agency. I was greatly impressed at the level of commitment shown by industry, business, user groups, and consumer representatives alike to the need for independent regulation. Here was clear support for the concept of legitimacy through open process.

It was striking how little support there was for the Department of Communications proposal at our hearings. For instance, senior officials had assured the Senate Committee at the outset of the hearings that there had been full and frank consultation in the early drafting stages of Bill C-62: “A standard question for all witnesses was: 'Had there been this type of advance consultation?' The invariable answer was: 'No!'”56 Senators were puzzled why it was that the CRTC was being praised, the Department damned. Were they not all just bureaucrats anyway? When Senator John Sylvain of Quebec (as he then was) put this question to Professor Richard Schultz of McGill University, he drew a distinction, which the Senate Committee found very helpful, between “open” and “closed” bureaucrats — "between those who relied on open procedures and seemed to lay all their cards on the table, and those who did not employ open procedures and always seemed to have some hidden agenda."57

While the Senate Committee succeeded in defeating closed ministerial licencing, it failed to persuade on two other crucial issues. The Senate Committee did not succeed in replacing a warm and fuzzy, yet often contradictory, motherhood statement of objectives with a statement clearly committed to competition and economic efficiency. Such a statement would have reinforced the direction in which the industry was starting to move. Nor did it succeed in removing what I have long called a "double whammy” regime of ex post Cabinet review of individual decisions and ex ante general policy directions. ${ }^{58}$ Elimination of Cabinet review of individual decisions had been recommended by the Law Reform Commission of Canada in its report on independent administrative agencies, ${ }^{59}$ and by the Economic Council of Canada in its Reforming Regulation report. ${ }^{60}$ However, as Priest insightfully noted, reviews

55 See HN Janisch, “At last! A new Canadian telecommunications act” (1993) 17:9 Telecommunications Policy 691 [Janisch, “At last!”].

56 HN Janisch, The Professor in the Sausage Factory: Some Thoughts Based on Experience as to What Went Into the New Telecommunications Act (Montreal: McGill University Centre for the Study of Regulated Industries, 1994) at 23.

57 Ibid.

58 Janisch, “At last!,” supra note 55 at 693-95. See also Richard Schultz, “Industry Canada as Economic Regulator: Globalive and the Lessons of Political Licensing” in Christopher Stoney \& Bruce Doern, eds, How Ottawa Spends, 2011-2012: Trimming Fat or Slicing Pork? (Montreal: McGill-Queen’s University Press, 2011) 198. Schultz has recently pointed out that ministerial licencing is still widely employed with respect to crucial spectrum allocation matters, and Industry Canada, rather than confining itself to technical matters, now claims a much wider ambit of authority.

59 Law Reform Commission of Canada, Report on Independent Administrative Agencies: A Framework for Decision Making, vol 26 (Ottawa: Law Reform Commission of Canada, 1985) [Independent Administrative Agencies].

$60 \quad$ Economic Council of Canada, Reforming Regulation (Ottawa: Supply and Services Canada, 1981) [Reforming Regulation]. 
of regulation by politicians and bureaucrats unanimously favoured the retention of Cabinet power over individual decisions. ${ }^{61}$

As far as I was concerned, the Economic Council of Canada had got it right in its recommendation that Cabinet override of individual decisions (ex post) should be eliminated in favour of general policy directions (ex ante). As the Council explained, this would focus political accountability where it would be a reality. Pursuing the ex ante format would give Ministers and their departments a forum in which to openly advance their policy concerns. It would reinforce the principles of responsible government in that the Cabinet would always eventually prevail, and then be held responsible in the legislature and at the polls. It would maintain the integrity and worth of regulatory agencies, but not at the expense of ultimate political accountability. It would, the Economic Council of Canada concluded, "be the cat's pajamas." 62

I must confess that the reference to feline sleepwear was lifted from a consultant's report I had written for the Council, never expecting that it would find its way into print. I have often wondered how it was translated into French!

I think, in large measure, bureaucratic and political concern to preserve two kicks at the regulatory policy can is based on the assumption that voters cannot distinguish between a government decision and one made by an independent regulatory agency - that they will hold politicians responsible regardless of who actually made the unpopular decision. If politicians are going to be held politically responsible, the argument runs, they should be able to do something about it. While a political realist may see this as perfectly understandable "selective accountability," the government will seek to retain the option of distancing itself from an unpopular decision by purporting the decision as having been made by an independent expert body. However, should the decision appear to be really politically damaging, then the government would still have residual authority to intervene and save the day.

As it turned out, governments were initially quite circumspect in the manner in which they approached their double-barrelled power in relation to the CRTC. As the influential Telecommunications Policy Review Panel (Review Panel) noted in its March 2006 report, the CRTC had been allowed to act with relative independence. ${ }^{63}$ The policy direction power had not once been used since it had been introduced in 1993. The Cabinet review power had only been employed on a few occasions when parties were strongly dissatisfied with a CRTC decision, but never by the government on its own initiative. ${ }^{64}$

This was, however, to prove to be something of a lull before the storm. Ironically, it was the Review Panel itself which made policy change possible. Armed with a highly credible Institutions and the Restructured Industry” in Ronald J Daniels, ed, Ontario Hydro at the Millennium: Has Monopoly's Moment Passed? (Toronto: University of Toronto Press, 1995) 355.

63 Telecommunications Policy Review Panel, Final Report 2006 (Ottawa: Public Works and Government Services Canada, 2006) at 9-16, online: Industry Canada <http://www.ic.gc.ca/eic/site/smt-gst.nsf/ vwapj/tprp-final-report-2006.pdf/\$FILE/tprp-final-report-2006.pdf> [Final Report 2006]. Ibid. 
and well thought-out policy prescription from the Review Panel, Maxime Bernier, the new Minister of Industry in the Harper government, soon showed that he was prepared to use the regulatory policy levers available to him.

In a wonderful account entitled, "Telecommunications Policy: What a Difference a Minister Can Make," ${ }^{65}$ Richard Schultz captured how Minister Bernier translated his marketoriented sense of mission (through the analysis and recommendations of the Review Panel) to make a dramatic change to the political-bureaucratic dynamic in the telecommunications sector. His driving energy, combined with a roadmap for reform set out by the Review Panel, led Minister Bernier to become the first Minister to actually use the full range of legal policy tools available to him. This was to involve trendsetting Cabinet reviews with respect to Voice over the Internet Protocol (VoIP) and the rate at which local competition was to be allowed. ${ }^{66}$ Even more striking was the first ever policy direction which, as Schultz noted, led to a "fundamental recasting" 67 of the Telecommunications Act's wishy-washy policy objectives.

What is interesting here is that there was no legal challenge to this fundamental recasting of the Telecommunication Act's policy objectives. Could the direction of power really be used to impose competition as a priority when the objectives section had deliberately refrained from establishing any such priority in its non-hierarchical list of things Canada could achieve through telecommunications? Could a subordinate legislative instrument a direction - reorder the policy objectives in the Telecommunications Act and require the regulator to follow this reordering? For me, it was as if the Senate Committee's approach had been adopted after all!

Here it would be useful to distinguish between repeat players and those with nothing to lose. It has been my experience that in regulation, repeat players are often reluctant to antagonize the hand that usually feeds them by way of court challenges, whereas smaller, one-shot players, whose very existence is at stake, are prepared to do so. ${ }^{68}$ Here, the incumbents, most of whom were advantaged by the direction, ever-so politely pointed out that while a policy direction could be used to clarify the Telecommunication Act's policy objectives, it could not be used to amend its provisions. They did not follow through with this concern and test the legal validity of the direction in court. However, as we will see in just a moment, the next time Cabinet sought to overrule a CRTC decision, there was a smaller, nothing-to-lose player prepared to take the government to court.

In the meantime, it became clear that the CRTC had finally "got it." As Chairman von Finckenstein acknowledged, Maslove, ed, How Ottawa Spends, 2008-2009: AMore Orderly Federalism?(Montreal: McGill-Queen’s University Press, 2008) 134 [Schultz, "Telecommunications"].

Ibid at 144-47, 151-57.

Ibid at 149.

See HN Janisch, "Reregulating the Regulator: Administrative Structure of Securities Commissions and Ministerial Responsibility" in Law Society of Upper Canada, ed, Special Lectures of the Law Society of Upper Canada: Securities Law in the Modern Financial Marketplace (Toronto: De Boo, 1989) 97 [Janisch, "Reregulating”]. 
the message is clear: the government wants to move quickly toward more reliance on market forces in telecom services, less regulation and smarter regulation. I welcome the clarity and I welcome the variation order [with respect to the introduction of local competition]. While it isn't precisely what we have chosen to do, it is a feasible alternative and you can be sure that we are going to implement it in a way that captures the spirit as well as the letter of what the government has said it wants to accomplish. ${ }^{69}$

As Schultz commented, this "gracious concession speech"70 concluded a 12-month series of battles that had been fought following the appointment of Maxine Bernier as Minister of Industry — battles the Minister had clearly won.

\section{USAge BASEd Billing: What ShOUld HAVE HAPPENED?}

First of all, the regulator should have done a much better job of explaining the basis of its decision. The decision itself was exceedingly terse, coming in at just four pages. ${ }^{71}$ This decision was almost entirely concerned with the need for a discount in wholesale rates for independent ISPs. This discount rate was then abruptly set at 15 percent, although as Bell Canada had submitted, no basis had been established to determine an appropriate level of discount. ${ }^{72}$ Just how abrupt the CRTC's decision had been may be seen in the four paragraphs which decided both the impact of wholesale UBB on ISPs and the level of discount required:

Further, the Commission notes its view in Telecom Regulatory Policy 2010-632 that services provided by smaller competitors bring pricing discipline, innovation, and consumer choice to the retail Internet service market. The Commission considers that, in the absence of a discount on carriers' wholesale UBB rates relative to their comparable retail UBB rates, smaller competitors' ability to continue to differentiate their retail Internet services would be unduly impaired.

In light of the above, the Commission concludes that wholesale UBB rates should be established at a discount relative to carriers' comparable retail UBB rates and that, in the absence of such a discount, the wholesale UBB rates would not be just and reasonable, contrary to subsection 27(1) of the Telecommunications Act (the Act).

Regarding the amount of the wholesale UBB discount, the Commission considers that if it is too large, the effectiveness of UBB rates as an economic ITMP [Internet traffic management practice] will be reduced, while if it is too small, competitors' capacity to recover costs will be undermined.

The Commission concludes that a discount of 15 percent for carriers' wholesale UBB rates relative to their retail UBB rates recognizes these considerations appropriately. ${ }^{73}$

These abrupt conclusions, rather than fully reasoned decisions, should be of concern. Did the CRTC display the level of "expertise" and "longer term perspective" that its supporters,

Schultz, "Telecommunications," supra note 65 at 157.

Ibid.

CRTC, 2011-44, supra note 4.

Ibid at para 6 .

Ibid at paras 11-14. 
such as Richard French, attribute to it? ${ }^{74}$ In an ideal regulatory world, it would have been this lack of quality in decision-making which would have brought the CRTC's decision down. ${ }^{75}$ In the less principled real world, it was to be the sweeping dismissal of broader concerns about UBB which galvanized opposition. As the decision acknowledged in passing, "the Commission also received a large number of public comments, generally opposing UBB."76 However, no attempt was made to respond to these heartfelt, often vehement concerns. This meant that when there was a broad ranging public and political outcry over issues such as equity, cost recovery, innovation, contrived competition, congestion, and confidentiality (as discussed earlier), the decision was largely unstructured by reference to any up-to-date, carefully thought-through analysis of the issues by the regulator. It is true that some of the issues had been dealt with two years earlier in the context of Internet traffic management practices, ${ }^{77}$ but that decision lacked the popular immediacy of UBB and seemed to be relatively far-removed from the concerns of most users. Going further down the road with UBB (especially in a manner which was likely to eliminate flat-rate service from independent ISPs) should have required the CRTC to restate and amplify its policy conclusions in terms that could be readily understood by the general public. If the CRTC had been wide-awake at the switch, it would have been aware of the intense interest of tech-savvy "heavy users" (as demonstrated in the 2009 net neutrality proceedings) and would have realized how easily these users could mobilize "average users" against the spectre of a "metered Internet."78 This is not to say that a fully reasoned decision would have, in itself, quieted the storm. Again, as French recognized, the CRTC would inevitably be buffeted by rent-seeking and special pleading no matter what. ${ }^{79}$ But the CRTC could have provided some way to channel discussion along more constructive lines, and also provided tangible support to the friends of the concept of independent regulation.

It is striking (as we have seen) that the CRTC's strongest arguments in favour of UBB were only to be raised by Chairman von Finckenstein before the Parliamentary Committee after a decision to recant had already been made. It hardly seems appropriate to hold back on one's underlying reasons for a decision until given an opportunity to speak from the gallows at a political hanging.

Minister Clement's initial response was fully in keeping with the Telecommunications Act when a week after the decision he indicated that the Cabinet would refer the decision back

French, "Second-guessing," supra note 47.

For an assessment of the adequacy of CRTC decisions, see HN Janisch, "Fairness and Transparency in Telecommunications Regulation” (2002) 16 Can J Admin L \& Prac 227 at 245-49.

CRTC, 2011-44, supra note 4 at para 4.

CRTC, Review of the Internet traffic management practices of Internet service providers (21 October 2009), Telecom Regulatory Policy 2009-657, online: CRTC <http://www.crtc.gc.ca/eng/archive/2009/ 2009-657.htm> [CRTC, 2009-657]. See also CRTC, Wholesale high-speed access services proceedings (30 August 2010), Telecom Regulatory Policy 2010-632, online: CRTC <http://www.crtc.gc.ca/eng/ archive/2010/2010-632.htm>.

The CRTC should have recalled the level of interest in traffic management practices and net neutrality it had encountered in 2009: “Canadians' interest in this subject was highlighted through submissions made to the Commission throughout the process. The Commission received 437 initial comments, 35 reply comments, and 34 final replies from parties (companies and advocacy groups) and individuals. In addition, an online campaign resulted in over 13,000 email submissions to the Commission from individuals. At the oral hearing in July 2009, 26 presentations were made. Finally, an online consultation initiated by the Commission resulted in 1,400 additional individual comments" (CRTC, 2009-657, ibid at para 10$)$.

French, "Second-guessing," supra note 47. 
to the regulator for reconsideration. As he put it, "[w]e can refer it back to the commission and say 'We'd like you to look further at this through government policy on competition, on innovation, on consumer choice."

This is precisely what is provided for through section 12(1) of the Telecommunications $A c t^{81}$ - it allows the Cabinet, on its own motion, to refer decisions back for reconsideration. Moreover, section 12(5) provides that in any reference back, the Cabinet shall set out the details of any matter it considers to be material to the reconsideration. Instead, as we have seen, Minister Clement delivered an ultimatum to the CRTC warning that its decision would be scrapped if the regulator did not rescind the decision itself. The Minister then indicated that in any "reconsideration," its decision must be changed, thereby asserting an extra-legal power of "anticipatory variance."

The CRTC would have been in a position to insist that the Cabinet follow the review procedures set out in the Telecommunications Act, had it had a more fully articulated decision to fall back on, or, if need be, a statement from the Chairman making it clear that the Commission had fully discharged its responsibilities and that there was now an established legal means for the government to respond. The CRTC instead set a very bad precedent by backing down to bullying politicians who lacked legal authority. Requiring the government to act within the confines of the law would have been preferable to any ostensible claim that the CRTC was acting on its own initiative in reconsidering its decision. This would have kept the regulatory process from degenerating into the status of a shouteddown referee at a boomerang tournament.

It might be suggested that this preferred solution ignores the urgency of the occasion. Was there enough time for legal niceties to be observed? Is not the Cabinet review process too slow and cumbersome? The Globalive Wireless Management Corp (Globalive) foreign ownership issue (to be discussed shortly), however, demonstrated just how expeditious the Cabinet review process can be, even when a detailed variance is made of a CRTC decision. Justice Sexton in the Federal Court of Appeal neatly captured the timelines involved:

On October 29, 2009, the CRTC issued Telecom Decision 2009-678 ... in which it concluded that Globalive is controlled by a non-Canadian and is therefore not eligible to operate as a telecommunications common carrier. The next day, the Minister of Industry announced that he intended to review the CRTC decision. He invited submissions from those who had participated in the CRTC hearings, as well as the provinces. The Minister also received comments from parties whose views were not directly solicited, including Public Mobile.

On December 10, 2009, the Governor in Council issued the Order in Council, finding that Globalive is not controlled by a non-Canadian, and thus Globalive became eligible to operate in Canada. ${ }^{82}$

Chase \& Marlow, “Ottawa enters dispute,” supra note 5.

Supra note 1.

Globalive Wireless Management Corp v Public Mobile, 2011 FCA 194, [2011] 3 FCR 344 at paras 6-7 [Globalive]. 
Even with an election looming, and especially when all that was needed was a reconsideration instead of a full-scale variance, being able to move from announcement to decision in 52 days suggests that the Cabinet review process would not have been too slow.

\section{A Muted COMPROMISE}

It had been widely expected in industry circles that when Konrad von Finckenstein, (who had been Commissioner of Competition and head of the Competition Bureau of Canada between 1997 and 2003) was appointed Chair of the CRTC in January 2007, he would, compatible with overall government policy, move the Commission away from regulation toward greater reliance on competition policy. However, as it turned out, on his watch the CRTC was considered by the Conservative government which had appointed him as not having made enough of a rapid transfer to competition. As we have seen, between March 2006 and April 2007, the government, at the urging of the dynamic Minister of Industry, Maxime Bernier, had fundamentally changed two of the Commission's major decisions and had imposed the first-ever general policy direction on the CRTC. ${ }^{83}$

Konrad von Finckenstein's tenure at the Commission was a stormy one: "Since he was appointed in 2007, Mr. von Finckenstein has butted heads with federal government officials and industry heavyweights, overseen drastic changes to the broadcast and telecom sectors in Canada, and testily scolded anyone at CRTC hearings he felt did not adequately answer his questions." 84

At a somewhat quieter level of interaction, it was evident that the government, in general, and Minister of Industry Tony Clement, in particular, objected to his public policy pronouncements relating to matters not directly assigned to him. For instance, on 6 May 2010 Minister Clement came out at a conference in Ottawa in favour of applying an across-theboard 51 percent Canadian ownership rule in telecommunications, just at a time that the government was considering developing separate rules for broadcasting and telecommunications. ${ }^{85}$ In an appearance before a parliamentary committee just ten days later, Minister Clement flatly contradicted Chairman von Finckenstein in stating that it might be possible to lessen restrictions on certain segments (particularly cellular radio) of the telecommunications sector without doing the same for the culturally-sensitive broadcasting industry. As he put it, “I’m not saying it's easy, but it certainly isn't impossible to draw the distinction." 86

Konrad von Finckenstein's appointment had been for five years, but he was eligible for reappointment. ${ }^{87}$ Apparently, he had sought an extension on his term, but in late September

See Schultz, “Telecommunications,” supra note 65 at 134, 144-49, 151-57.

Susan Krashinsky, “CRTC chairman won't get a second term,” The Globe and Mail (27 September 2011), online: The Globe and Mail <http://www.theglobeandmail.com/report-on-business/crtc-chairmanwont-get-a-second-term/article595789/> [Krashinsky, “Second term”].

CRTC, News Release, "Speech by Konrad von Finckenstein at Canada 2020 Panel on 'Telecom in Canada: A New Owner's Manual”” (6 May 2010), online: CRTC < http://www.crtc.gc.ca/eng/com200/ 2010/s100506.htm>.

Iain Marlow, “Clement hints Ottawa, not CRTC, will drive policy,” The Globe and Mail (14 May 2010) B5.

Canadian Radio-television and Telecommunications Commission Act, RSC 1985, c C-22, s 3(3). 
2011, it was curtly denied. ${ }^{88}$ Thus, the CRTC moved to reconsider its UBB decision with a lame duck Chair and under a cloud of popular and political criticism. Moreover, when the government appointed Tom Pentefountas, Vice-Chairman (Broadcasting) it made no attempt to relate his qualifications to those required of an expert regulator. "The job description for the position, which pays between $\$ 190,400$ and $\$ 224,000$ per year, says successful candidates should have a degree or job experience in a related field of study to the CRTC, as well as senior-level decision-making experience, familiarity with the regulator's framework and knowledge of the broadcasting industry." 89 It would seem that he was appointed, over three sitting CRTC Commissioners, by way of his political contacts and work with the Montreal Helenic Chamber of Commerce. ${ }^{90}$

Under these circumstances, it could be no surprise that the CRTC's reconsideration was a muted compromise. ${ }^{91}$ Gone was the Chairman's strong support for UBB as a matter of "fundamental fairness." 92 Concern now was to give ISPs greater flexibility in offering competitive services. The reconsidered decision simply did not address the wider issues raised earlier in the debate about UBB such as equity, cost recovery, innovation, contrived competition, congestion, and confidentiality. ${ }^{93}$ Mirko Bibic noted that the major policy issues had been "put to bed." 94 To continue with the domestic theme, it is probably more accurate to say that they had been "swept under the carpet."

While the UBB issue was not directly addressed (with the CRTC keeping its focus only on wholesale rate structures), it is important to note that in adopting its "capacity-based approach," the CRTC, in effect, adopted the discipline inherent to UBB. As Bibic observed with obvious satisfaction in analogizing UBB use to highway lanes, "I think the philosophy is [to] put the independent ISP in a position of responsibility. If usage goes up, you're going to have to buy more lanes - it's the same decision that we have to make."95 Indeed, the Commission went out of its way to emphasize this aspect of its new capacity-based approach: "By determining in advance the bandwidth they need, independent ISPs assume the risk and responsibility associated with planning and managing the impact their customers will have

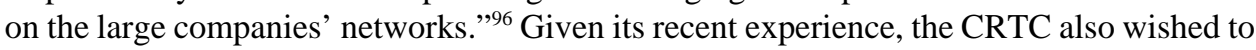
emphasize that it was not directly mandating UBB, and thus could not be blamed if it was adopted by the independent ISPs. In explaining that it had approved two wholesale billing models (the existing flat-rate and new capacity-based models) to give independent ISPs flexibility in developing innovative business models, it went on to state: "[T]he models do not contain any provisions that would require independent ISPs to impose bandwidth caps

88 Krashinsky, "Second term,” supra note 84.

89 Gloria Galloway, “CRTC appointment smacks of cronyism, NDP says,” The Globe and Mail (4 February 2011), online: The Globe and Mail <http://www.theglobeandmail.com/news/politics/ottawa-notebook/ crtc-appointment-smacks-of-cronyism-ndp-says/article1895426/email/>.

$90 \quad$ Ibid.

$91 \quad$ CRTC, Billing practices for wholesale residential high-speed access services (15 November 2011), Telecom Regulatory Policy CRTC 2011-703, online: CRTC < http://www.crtc.gc.ca/eng/archive/2011/ 2011-703.htm>.

CRTC, “News Release," supra note 27.

See Part III above.

Iain Marlow, "CRTC unveils compromise for usage-based billing,” The Globe and Mail (15 November 2011), online: The Globe and Mail <http://www.theglobeandmail.com/technology/tech-news/crtcunveils-compromise-for-usage-based-billing/article4085249/>.

Ibid.

CRTC, News Release, “CRTC supports choice of Internet services” (15 November 2011), online: CRTC <http://www.crtc.gc.ca/eng/com100/2011/r111115.htm>. 
on their retail customers. The decision to impose such caps is left to the ISP and not mandated by the CRTC."97

In view of their dependency, the independent ISPs, who initially welcomed the decision, inevitably complained about the wholesale rates they would now have to pay. ${ }^{98}$ Once again, one is reminded that the regulator relies on the weakest players in the sector so much for competition and innovation. Should the CRTC continue to assume that there will only be inadequate competition in a cable and telecommunications company duopoly, or should it concentrate on improving the quality of competition between the big players, rather than continue to prop up the independent ISPs? But, that question would clearly be beyond my present terms of reference!

\section{FOREIGN OWNERSHIP CONCERNS}

As we moved further towards a more competitive telecommunications environment, it became clear that there was a shortage of investment capital in Canada, especially for newentrant cellular radio carriers seeking to challenge the well-entrenched incumbents such as Bell Canada, Telus, and Rogers. The Review Panel called for some relaxation on our overly restrictive foreign investment rules, ${ }^{99}$ but the trouble was that the foreign investment rules were contained in the 1993 Telecommunications Act itself, ${ }^{100}$ and there appeared to be little chance of legislative change during a fractious minority government.

Globalive, a successful participant in an auction of spectrum, had extensive investment from a major Egyptian cell phone company and was subject to an unusual degree of scrutiny by the CRTC which, in the end, ruled that it was not in compliance with the Act ${ }^{101}$ The Cabinet, on its own motion, varied the decision to approve Globalive's investment structure. ${ }^{102}$ Public Mobile, another small new-entrant cellular competitor, felt that it had been disadvantaged by its compliance with an earlier understanding of the foreign ownership investment limits and challenged the Cabinet's decision by way of judicial review at the Federal Court.

On 4 February 2011, Justice Hughes declared the Cabinet's decision to be null and void in that it had been determined on a basis of law not provided for in the Telecommunications Act. ${ }^{103}$ The Governor-in-Council had misdirected itself in law by interpreting the Canadian ownership and control requirements in a way that ensured access to foreign capital, technology, and business experience was encouraged. However, the Act did not refer anywhere to foreign investment or to the benefits of foreign capital, technology, and business

$97 \quad$ Ibid [emphasis in original].

See e.g. Canadian Network Operators Consortium (CNOC), Press Release, "CNOC is very concerned about the latest CRTC wholesale service rate decisions” (15 November 2011), online: CNOC <http:// www.cnoc.ca/articles/articles/view/cnoc-is-very-concerned-about-the-latest-crtc-wholesale-service-r ate-decisions $>$.

$99 \quad$ Final Report 2006, supra note 63 at 11-14, 11-26.

$100 \quad$ Supra note 1 , s 16.

101 CRTC, Review of Globalive Wireless Management Corp under the Canadian ownership and control regime"(29 October 2009) Telecom Decision CRTC 2009-678, online: CRTC <http://www. crtc.gc.ca/eng/archive/2009/2009-678.htm>. 
experience. What the Act did say was that telecommunications had an essential role to play in the maintenance of Canadian identity and sovereignty, and included a policy objective which required that Canadian ownership and control be promoted. By contrast, there was no policy objective in the Act that encouraged foreign investment.

Coming when it did — just as the whole UBB issue was coming to a boil — this decision was seen as adding further to the confusion over who was in charge of telecommunications policy. However, as it limited the authority of the Cabinet, it was also seen as enhancing the role of the independent regulatory agency. ${ }^{104}$ Subsequently, the government's successful appeal, ${ }^{105}$ along with the CRTC's reconsideration of its UBB decision, seemed to indicate that the pendulum was swinging back in favour of the government.

The Federal Court of Appeal adopted an essentially deferential attitude to Cabinet's decision. ${ }^{106}$ As a matter of statutory interpretation, while the Court was unable to decide whether a correctness or reasonableness standard should be applied, it concluded that under either standard the variance should be upheld. As for the application of the crucial "control in fact" test, the Court held that the divergence between the CRTC and the Cabinet involved factual inferences or conclusions drawn from the evidence: "The Governor in Council simply had a different appreciation of things, and that appreciation was rational and defensible.”107 As well, Justice Sexton made clear that the nature of the decision-maker and the nature of the decision to be made had to be taken into account:

\footnotetext{
In my view, the Governor in Council is not restricted to assessing control in fact only as a corporate lawyer would. Once again, the fact Parliament chose to grant the Governor in Council the right to review the CRTC's application of the control in fact test implies the decision was intended to incorporate policy concerns when appropriate. The control in fact test is also necessarily contextual and somewhat imprecise. Determining where control in fact lies may require weighing a number of competing factors. The Governor in Council may legitimately consider the statutory context in deciding how to strike this balance. ${ }^{108}$
}

Public Mobile sought leave to appeal to the Supreme Court of Canada. ${ }^{109}$ The new Minister of Industry, Christian Paradis, unlike Maxime Bernier, seems to be adopting a cautious approach to foreign ownership. ${ }^{110}$ The future for new entrant competitors in wireless

Steven Chase, “Telecom foreign ownership case a test of cabinet power,” The Globe and Mail (18 January 2011), online: The Globe and Mail <http://www.theglobeandmail.com/news/politics/telecomforeign-ownership-case-a-test-of-cabinet-power/article562541/>; Iain Marlow, Rita Trichur \& Jacquie McNish, "Court scraps cabinet ruling on Globalive, dealing blow to new entrant," The Globe \& Mail (4 February 2011), online: The Globe and Mail <http://www.theglobeandmail.com/news/technology/ tech-news/ubb-internet/article1895592.ece>; Steven Chase, "Telecom ruling puts a leash on Tory cabinet authority,” The Globe and Mail (4 February 2011), online: The Globe and Mail <http://www. theglobeandmail.com/technology/tech-news/court-scraps-cabinet-ruling-on-globalive-dealing-blow-tonew-entant/article572948/>.

Globalive, supra note 82.

Ibid.

Ibid at para 44 .

Ibid at para 50.

Ibid, leave to appeal to SCC refused 34418 (26 April 2012).

Daniel Leblanc, Barrie McKenna \& Iain Marlow, "For new Industry Minister, a steep learning curve,” The Globe and Mail (18 May 2012), online: The Globe and Mail <http://www.theglobeandmail.com/ news/politics/for-new-industry-minister-a-steep-learning-curve/article2027448/>; Steven Chase \& Iain Marlow, "Ottawa wavering on telecom restrictions,” The Globe and Mail (31 May 2011), online: The Globe and Mail <http://www.theglobeandmail.com/news/politics/ottawa-wavering-on-telecomrestrictions/article2041513/>. 
telecommunications seems precarious to say the least. ${ }^{111}$ Certainly, Egyptian billionaire Naguib Sawiris of Orascom, who has invested heavily in Globalive, is far from happy. He says he was "misled by the Canadian government, regrets 'totally' his decision to invest [in Canada]," ${ }^{\prime 12}$ and is telling other international financiers not to invest here. He said: "But to say, 'We want to create competition, we want your money.' They take our money and they leave us to the dogs." ${ }^{\text {"113 }}$ Canada is now paying the price for having delayed so long in opening up the telecommunications industry fully to foreign investment.

\section{Aspects of Energy Regulation}

While I believe that recent telecommunications experience is particularly relevant to an understanding of my overall topic, given the focus of this conference, I now need to move on to some energy regulatory matters at both the federal and provincial level.

We have to recognize that the vagaries of history play a large role in determining institutional relationships in government. Telecommunications, initially, was dealt with out of convenience, tucked in under broad-based federal railway legislation with its quintessential Canadian compromise over regulatory independence and political control. Earlier, the Cabinet had dealt with ever-controversial railway rates directly, but Cabinet came to recognize that it would be prudent to give much of that responsibility to a (relatively) independent Board of Railway Commissioners, while retaining Cabinet review as a fall-back type of political safety valve. ${ }^{114}$ With continuity in mind, the 1993 Telecommunications Act adopted essentially the same scheme established for the regulation of railway rates. By way of contrast, when the National Energy Board (NEB) was set up in 1959 it was not modelled along the lines of the transport commission, but rather on the by then well-established and independent Alberta Oil and Gas Conservation Board (AOGCB). As the history of the NEB notes (in reference to the influential head of the AOGCB who went on to be the first chairman of the NEB), "[i]t was not just that Ian McKinnon was an Albertan, nor that so many of his staff came from Alberta. They brought with them an Alberta model for an energy board, the Oil and Gas Conservation Board.”115

Moreover, at the time the NEB was established, ${ }^{116}$ there was no energy department in the federal government with expertise in oil and gas matters, and as a result the NEB was expected to play a major advisory role from the outset. ${ }^{117}$ In short, it would be an exporter of policy, not an importer. Indeed, there is no provision in its act for general policy directions from government, or any power in the Cabinet to review or rescind its decisions. With respect to tariffs, NEB decisions are subject only to appeal, with leave, to the Federal Court

Iain Marlow, "Wireless upstart model failing, future grim: analyst,” The Globe and Mail (21 November 2011), online: The Globe and Mail <http://www.theglobeandmail.com/news/technology/mobiletechnology/wireless-upstart-model-failing-future-grim-analyst/article2243395/>.

112 Iain Marlow \& Rita Trichur, "Wind Mobile's backer blasts Ottawa, regrets investment," The Globe and Mail (18 November 2011), online: The Globe and Mail <http://investdb4.theglobeandmail.com/servlet/ story/GAM.20111118.RBWINDOWNERSHIP1118ATL/GIStory>.

113 Ibid.

114 See generally Howard Darling, The Politics of Freight Rates: The Railway Freight Rate Issue in Canada (Toronto: McClelland and Stewart, 1980).

115 Earle Gray, Forty Years in the Public Interest: A History of the National Energy Board (Vancouver: Douglas \& McIntyre, 2000) at 24.

116 National Energy Board Act, RSC 1985, c N-7.

117 Ibid, Part IV. 
of Appeal on questions of law or jurisdiction. ${ }^{118}$ With respect to facilities, the Board is authorized to issue certificates subject to the approval of the Governor-in-Council. ${ }^{119}$ Most importantly, there is no power given to the Cabinet to vary or amend a certificate. As a matter of long-established practice, the Cabinet invariably approves Board certificates. I understand that there has only been one instance in recent years where certificate approval was even delayed for a substantial period.

The contrast with telecommunications regulation is striking, particularly so in recent years. While one needs to keep in mind Governor-in-Council regulations applied to the Board, as well as the substantial involvement of Ottawa in international matters, the NEB stands as a fully-fledged independent regulatory agency — something of an exception at the federal level in Canada. ${ }^{120}$

What interests me is that the role and responsibilities envisaged in 1959 seem to have been of an essentially technical and economic nature - of intense interest and concern to industry repeat players, but of relatively little interest to the general public. Although the structure of the legislation has not been changed, the overall context within which the Board now operates, and the range of participants in its processes, have changed a considerable extent. The question I would like to raise is whether, especially in regard to hugely increased environmental concerns, this change in emphasis might change the nature of relationships with government. Putting it bluntly, will there now be efforts by those not satisfied with Board decisions to resort to the Cabinet in seeking to block approval? Repeat players in industry may be willing to live with an adverse decision in hopes of a more favourable one next time, but one-shot, one-issue environmental interveners may be prepared to seek a political override solution.

Of course, environmental participants themselves may have already become repeat players not keen on upsetting the familiar regulatory applecart where they may have had some success (I recall that when I chaired the Regulated Industries Program of the Consumers' Association of Canada in the 1980s, we often felt more comfortable arguing before the regulator than straying into the less structured and predictable political field). Moreover, there is no clear route laid out for political intervention when it comes to the NEB. Recall that a determined consultant with no legal assistance was able to put together a petition to Cabinet which could have legitimated the whole UBB protest (had Minister Clement been more patient). In effect, the Telecommunications Act invites political second-guessing and sets out the process to be followed in so doing. There is, of course, no similar roadmap with respect to the NEB, or even a means of getting a matter on the Cabinet agenda. And it may well be that participants in the Board's processes feel that they receive a fair hearing, and that their concerns are adequately addressed. As well, recent Cabinets may not be seen as receptive to environmental issues as they were to Internet competition and consumer choice. Finally, in tariff matters for example, the NEB may not be seen as making decisions which have an immediate and direct impact on individuals, and thus will not be likely to stir up an

Priest, supra note 53 at 22. Interestingly, although the Nielson Task Force on Agencies in the mid-1980s did recommend that the NEB be brought into line with other federal regulatory agencies and be made subject to both Cabinet policy directions and review, nothing came of this proposal. 
uprising compared to unlimited Internet access - the new Canadian birthright. This wholesale, rather than retail, character of the NEB's responsibilities is vastly different from provincial energy regulation and it is to this that I now turn.

Here in Alberta, as I am sure many of you will recall, there has been a revealing recent row about who should do what with respect to the upgrading of the province's electrical transmission system. With Bill 50, the proposed Electric Statutes Amendment Act, 2009, ${ }^{121}$ introduced in June 2009, the government said that it was taking responsibility to identify what new transmission infrastructure was needed, while leaving the independent regulatory process in place to address public concerns as to exactly where new facilities were to be located. ${ }^{122}$ This would have authorized the Cabinet to make the exempting "critical" designation without the "need" issue being vetted by the Alberta Utilities Commission (AUC) as in the past. As well, while the AUC would still have responsibility for approving critical transmission applications, its authority would have been substantially curtailed considering it would no longer be authorized to fully consider the public interest, including economic and environmental considerations. ${ }^{123}$

After a long, hot summer of protest, the government announced amendments to Bill 50 in November 2009, designed to provide greater clarity with respect to the role of the regulator. ${ }^{124}$ This would allow the AUC to make a decision as to precisely where critical transmission lines would be located and to consider the social, economic, and environmental effects of transmission line placement. This seemed to reach for the elusive compromise between regulatory independence and political control, in that it gave the government authority to ensure that critical transmission facilities were built (for which the government would be held politically accountable), and gave the regulator authority to ensure that, in implementing government policy the public interest would be protected. ${ }^{125}$

A decision as to who had the authority to decide what was made by the AUC on 1 November 2011 with respect to the Heartland Transmission Project, the first critical transmission infrastructure project to be considered by the AUC under the new legislative scheme. ${ }^{126}$ In this instance, the Legislature itself had declared the precise type of transmission line to be a critical project. Nevertheless, there were widely divergent views as to just what the AUC should include in its public interest review.

Bill 50, Electric Statutes Amendment Act, 2009, 2nd Sess, 27th Leg, Alberta, 2009 (assented to 26 November 2009) [Bill 50].

122 Government of Alberta, News Release, "New Legislation to help ensure much needed power lines are built” (1 June 2009), online: Government of Alberta <http://alberta.ca/acn/200906/261149D4CF393F6A4-BFBD-73258BC6700DF959.html>.

123 Laura Bowman, "Bill 50 Delivers Shocks to Electricity Planning Process" (2009) 24:3 Environmental Law Centre News Brief 1, online: Environmental Law Centre < http://www.elc.ab.ca/Content_Files/ Files/NewsBriefs/Vol24No3.pdf>.

124 Government of Alberta, News Release, "Province introduces amendments to electricity bill” (19 November 2009), online: Government of Alberta <http://alberta.ca/acn/200911/273620E773B0DEFB8-9764-0F2E6088FA5AC665.html>.

125 Bill 50, supra note 121, amending the Alberta Utilities Commission Act, SA 2007, c A-37.2, s 17. online: AUC <http://www.auc.ab.ca/applications/decisions/Decisions/2011/2011-436.pdf > . 
The applicants in the Heartland Transmission Project decision argued that the AUC had to confine itself strictly to which route and technical design option was in the public interest. A project would always be in the public interest where it provided the benefits intended by the legislature while "minimizing or mitigating to an acceptable degree, potentially adverse impacts on the community." "27 By contrast, the interveners contended that, given the AUC's broad public interest discretion, statutory approval of the need for a project designated as critical transmission infrastructure did not prevent the AUC from reviewing the overall social and economic effects of the project to determine whether an approval would be in the public interest. $^{128}$

In a thoughtful and thorough decision, the AUC concluded that where there was a critical infrastructure designation, the need and the inherent impacts of the technical solution had to be considered to be in the public interest. The AUC well captured the significance of Bill 50's enactment when stating:

The Commission concludes that the legislature, having assumed jurisdiction over the approval of the need for critical transmission infrastructure, is now responsible for determining the need for critical transmission infrastructure including all of its constituent elements. The effect of this change is that, when deciding upon a facility application for critical transmission infrastructure, the Commission must not address the matters which the legislature has already addressed when designating a project to be critical transmission infrastructure. To reconsider the need for a project or the suitability of the technical solution would be contrary to the legislative intent, and would result in a regulatory process that does not minimize costs and is inefficient and would be inconsistent with the stated purposes of the Electric Utilities Act. ${ }^{129}$

This did not mean that whenever there was a specific application for a critical transmission infrastructure project it would automatically be deemed in the public interest. The AUC still had jurisdiction to ensure that the application was consistent with the technical solutions identified in the first stage and then whether the proposed facilities minimize or mitigate to an acceptable degree potential adverse impacts on more discrete parts of the community, having regard to the social, economic, and environmental impacts of approving that specific application.

Viewed schematically, the AUC held that normally there would be no overlap between public interest tests in determining need and those in determining route and technical solutions. However, this did not mean that the Commission would never be concerned with the public interest determination made at the need level:

In an extreme case the Commission may reject an application for a specific project where it determines that the transmission facility, as proposed, will have unacceptable impacts, whether those impacts be provincial in scope or site specific, and that those impacts cannot be minimized or mitigated to an acceptable degree by Commission-ordered changes to the plans, specifications or routing of the proposed facility. What the Commission cannot do, however, is reject the application by finding that any application that meets the need would not be in the public interest only because of the social, economic and environmental impacts inherent 
in the technical solution and that would occur regardless of the design, configuration or routing proposed in the application. To do so would be to find that those inherent impacts are not in the public interest, which would be contrary to the express direction of subsection 17(2) of the Alberta Utilities Commission Act. ${ }^{130}$

\section{INTERESTING TIMES IN BRITISH COLUMBIA}

Let me turn briefly to recent developments in my new home province of British Columbia, and then return to Alberta for a short assessment of the Alberta Public Agencies Governance Act. ${ }^{131}$ I will then conclude with something by way of an overall assessment of where we stand in regard to the relationship which should exist between governments and independent regulatory agencies.

In British Columbia, the previous Gordon Campbell provincial government had had an ambitious environmental agenda and was concerned to make sure that the British Columbia Utilities Commission (BCUC) would put it into effect in regulating BC Hydro. In the revised Utilities Commission Act, ${ }^{132}$ the regulator was made subject to a sweeping power of direction with respect to the exercise of its powers and the performance of its duties, with which it had to comply despite any provision of its Act or the Clean Energy Act ${ }^{133}$ (of which more in a moment) or any previous decision it may have made. ${ }^{134}$ King Henry VIII would no doubt have approved of this assertion of executive power to dispense with acts of parliament! Interestingly, the Utilities Commission Act went on to provide that the Cabinet could not "specifically and expressly" declare an order or decision of the BCUC to be of no force or effect. ${ }^{135}$ This is in keeping with a decision made earlier in British Columbia to eliminate Cabinet appeals. ${ }^{136}$ At the same time, in overturning a controversial BCUC decision on rate rebalancing, the government indicated that it would be prepared to overrule any unacceptable BCUC order or decision by way of legislation. ${ }^{137}$

The Clean Energy Act contains a long recitation of "British Columbia's energy objectives." 138 In view of what happened with respect to the unstructured "Canadian Telecommunications Policy" discussed earlier, it should be noted that the Cabinet is specifically authorized to issue guidelines regarding the relative priority to be assigned to the various energy objectives. ${ }^{139}$

In electrical energy matters, British Columiba combines government ownership and independent regulation; a potentially explosive mix. This can be seen in a chronology

Ibid at para 154

132 SA 2009, с A-31.5 [APAGA].

132 RSBC 1996, c-473.

SBC 2010, с 22.

134 Utilities Commission Act, supra note 132, ss 3(1)-(2).

Ibid, s 3(3).

136 Cabinet Appeals Abolition Act, SBC 1993, с 38.

British Columbia Hydro and Power Authority 2007 Rate Design Application Phase - 1 (26 October 2007), BCUC Decision, online: BC Hydro < http://www.bchydro.com/etc/medialib/internet/documents/ info/pdf/info_bcuc_decision_october_26_2007_rate_design_applic.Par.0001.File.info_bcuc_decision_ october_26_2007_rate_design_applic.pdf $>$, overturned by the Utilities Commission Amendment Act, SBC 2008, c 13.

Clean Energy Act, supra note 133, Part I.

Ibid, s 35(f). 
highlighting the interplay between politicians and regulators with respect to BC Hydro's latest rate application. ${ }^{140}$

- $\quad$ On 26 February 2011, Christy Clark was selected leader of the governing British Columbia Liberal Party after criticizing proposed BC Hydro rate increases as inconsistent with her "families first" campaign. ${ }^{141}$

- $\quad$ On 1 March 2011, BC Hydro filed a revenue requirement application with BCUC seeking a 9.73 percent increase in each of the next three years, and pending final disposition of its application, an interim rate increase of 9.73 percent effective 1 April 2011.

- On 14 March 2011, Clark was sworn in as Premier and a new Cabinet was appointed, with Rich Coleman, the Minister of Energy and Mines, made responsible for BC Hydro. Coleman has a reputation of getting things under control and a tough-mindedness demonstrated in earlier posts, including being responsible for lottery and insurance corporations.

- $\quad$ On the same day the new Premier was sworn in, BCUC granted an order approving the interim rate increase.

- In the weeks following his appointment, Minister Coleman indicated he intended to review any BC Hydro rate increase.

- $\quad$ At the 24 March 2011 procedural conference on its rate application, BC Hydro sought a delay on the basis that the government would be reviewing its requested rate increase and that some form of downward adjustment would likely be made.

- $\quad$ On 28 March 2011, BCUC suspended the interim rate increase, directing BC Hydro to file for a new rate increase.

- $\quad$ On 31 March 2011, BC Hydro sought another delay, explaining that it was not yet in a position to provide further clarity on the government's planned review of its proposed rate increases.

- $\quad$ On 7 April 2011, Minister Coleman created a Review Panel for BC Hydro to "provide recommendations and options to ensure costs are minimized and benefits to B.C. families and BC Hydro customers are maximized.”142

This chronology is largely set out in the recitals to BCUC in BCUC, Utilities Commission Act and British Columbia Hydro and Power Authority; F2012 to F2014 Revenue Requirements Application (21 April 2011), Order Number G-72-11, online: BCUC < http://www.bcuc.com/Documents/Proceedings/ 2011/Doc_27532_A-11_G-72-11_Interim-Rates-Process.pdf> [BCUC, G-72-11].

“Jobs plan key to Clark's 'family-first' agenda," Vancouver Sun (28 January 2012), online: Vancouver Sun <http://www.vancouversun.com/business/Jobs+plan+Clark+family+first+agenda/6066804/story. html>.

142 BC Hydro, Press Release, "Review of BC Hydro aims to lower rate increases” (7 April 2010), online: BC Hydro <http://www.bchydro.com/news/press_centre/press_releases/2011/rates_review.html>. 
- The Review Panel's Terms of Reference noted that it was not intended to alter or interfere with the normal, more detailed review undertaken by BCUC.

- $\quad$ On 8 April 2011, BC Hydro requested an interim rate increase from BCUC of 8.23 percent effective May 1.

- $\quad$ On 20 April 2011, BC Hydro was granted a 8.00 percent interim rate increase.

- $\quad$ The BCUC stated: "This increase is approved on an interim and refundable basis pending the receipt of additional information following the Government Panel review."143

In announcing the review of BC Hydro by three senior government officials, Minister Coleman said, “[m]y expectation is we will find some efficiencies and savings we can pass back to the ratepayer," "144 and "[t]here's an ability to bring some of these rates down and still sustain the company at the level it should be." 145 A new, more modest rate application could follow this identification of cost savings and lead to a substantially lower rate request, which is more in keeping with the Premier's “families first” agenda.

Should we be concerned that regulatory independence and integrity may be being used to validate an outcome that is in reality pre-determined by the government through its shareholder control of the application process? Is this essentially to return to Richard Schultz's classification of “closed” rather than "open” regulation? Or does it constitute a commendable effort to preserve the independence and integrity of the regulator in the difficult context of a government-owned utility and rapidly changing political circumstances? In any event, is this type of maneuvering inevitable when government ownership bumps into independent regulation?

Rich Coleman's confident expectation as to the nature of the findings of the Review Panel was borne out in the Review Panel's detailed report, Review of BC Hydro, ${ }^{146}$ released on 11 August 2011. The report called for $\$ 800$ million in spending cuts over the next three years, which were to be found by delaying capital projects, reducing operating costs, acting on rosier forecasts for revenues, and stretching out loan repayments over longer periods. ${ }^{147} \mathrm{With}$ respect to operating costs, the Review Panel was particularly critical of a 41 percent employee growth between 2006 and 2010, with overall employment rising from 3,976 to

BCUC, G-72-11, supra note 140 at 3.

Richard Zussman, “Hydro system under scrutiny,” 24 Hours Vancouver (7 April 2011), online: Canoe <http://vancouver.24hrs.ca/News/local/2011/04/07/pf-17916991.html>.

Ian Bailey, “B.C. Liberals rule out controversial hydro-rate hikes,” The Globe and Mail (7 April 2011), online: The Globe and Mail <http://www.theglobeandmail.com/news/british-columbia/bc-liberals-ruleout-controversial-hydro-rate-hikes/article1974867/?services=mobile>. See also Justine Hunter, "Hydrorate hike put on hold," The Globe and Mail (29 March 2011) S1; Justine Hunter, "Minister expected to rein in Hydro rates," The Globe and Mail (4 April 2011) S1.

John Dyble, Peter Milburn \& Cheryl Wenezenki-Yolland, Review of BC Hydro (Victoria: Government of British Columbia, June 2011), online: Government of British Columbia <http://www.newsroom.gov. bc.ca/downloads/byhydroreview.pdf $>$ [Review].

Justine Hunter, “\$800-million in cuts to BC Hydro urged,” The Globe and Mail (11 August 2011), online: The Globe and Mail <http://www.theglobeandmail.com/news/british-columbia/800-million-incuts-to-bc-hydro-urged/article590631/> [Hunter, “\$800-million in cuts”]. 
5,615 resulting in a significant impact on costs. ${ }^{148}$ Moreover, BC Hydro employed approximately 650 engineers which was about six times more than the Ministry of Transportation with a similar sized capital program. The Panel recommended that full-time positions be cut to 4,800. ${ }^{149}$ Minister Coleman indicated that while he agreed with the Panel's recommendations, he would leave implementation up to the utility, including the selection of capital projects to be suspended. In response, BC Hydro's CEO, Dave Cobb, while saying that he was prepared to act on most of the recommendations, bridled at the drastic employment reductions, insisting that increases had come about as a result of the government's emphasis on conservation and the need for greater focus on customers. ${ }^{150}$ Shortly thereafter, Cobb, who had only been at BC Hydro for 17 months, resigned to join the private sector. ${ }^{151}$ While he denied that government intervention had led to his departure, it seems clear that the siren song of the private sector had become much more seductive as a result of incessant bureaucratic and political second-guessing. ${ }^{152}$

With respect to the immediate issue of rates, the Review Panel and BC Hydro executives worked together to find areas where costs could be reduced in the short term. Based on this collaborative effort the Review Panel concluded that BC Hydro could, with careful management, reduce its original rate increase application of an "unacceptable" 9.73 percent each year to an increase approximately half that amount. ${ }^{153}$ Of course the danger in employing ambitious government officials in this review process is that they may simply act as "echosultants" giving the politicians back precisely what the government officials know the politicians want to hear about in the short-term, not what the politicians should hear about for the long-term. Congruence between the Review Panel's report and the government's overall policy agenda should not be considered as purely coincidental.

The most controversial aspect of the Review Panel's recommendations concerned its call for reconsideration of the province's demanding commitment to energy self-sufficiency. The Review Panel suggested that, given changed circumstances, the existing self-sufficiency definition might be overly conservative and place an undue burden on BC Hydro ratepayers: ${ }^{154}$

As the British Columbia government mulls its energy future, self-sufficiency remains a goal.

But the goal posts could move.

Current provisions call for B.C. to be energy-sufficient by 2016, with minimum thresholds set at critical water levels — based on a low-water scenario last recorded in the 1940s.

Review, supra note 146 at 5-6.

Ibid.

Hunter, “\$800-million in cuts,” supra note 147.

Rod Mickleburgh, "BC Hydro boss quitting to rejoin private sector,” The Globe and Mail (19 October 2011), online: The Globe and Mail < http://www.theglobeandmail.com/news/british-columbia/bc-hydroboss-quitting-to-rejoin-private-sector/article558284/>.

Gary Mason, “Clark’s arrival complicated job for BC Hydro CEO,” The Globe and Mail (20 October 2011) S1.

Review, supra note 146 at 4.

Ibid at $10-11$. 
To meet that requirement, B.C. Hydro would have to [boost] its electricity supply by building new power projects or by buying hundreds of millions of dollars worth of long-term power from independent power producers.

Tweaking the requirement to suit average water levels, with some extra energy built in for insurance, would be one way the province could revamp the policy and reduce anticipated costs for ratepayers, says Energy Minister Rich Coleman. ${ }^{155}$

Bluntly put, there is concern that if, in response to limits on rates, BC Hydro were to cut back on upgrading its hydroelectric generation capacity, BC Hydro would have to resort to “dirty" sources of power. ${ }^{156}$ This concern has been greatly compounded by a newly announced employment policy which envisages new and expanded mines, as well as new shale gas and liquefied natural gas facilities. These are all heavy power users and may necessitate the importation of coal-generated power, or the on-site use of fossil fuels such as natural gas. ${ }^{157}$

Taking a step standing back from the immediate issues, we may see that what is involved is a classic short-term/long-term dichotomy, best resolved by respect for independent regulation. For a generation, BC Hydro and the British Columbia government have been able to avoid large-scale investment in new capacity by relying on the legacy of Premier WAC Bennett who made massive, long-term investments in upgradeable hydro dams, despite criticism at the time. This was supposed to change

when BC Hydro announced it needed \$6-billion to upgrade its crumbling infrastructure, much of it built in the 1960s under the firm direction of Mr. Bennett.

But [this] investment was deemed folly as well, for it would require hefty increases in Hydro rates to pay for it. Current Premier Christy Clark has put short-term politics first, ordering the Crown corporation to scale back its plans to the bare minimum to keep rate increases in check. ${ }^{158}$

Leaving BC Hydro's rate increase applications to be dealt with by the BCUC, instead of cutting them off at the shareholder pass, would have allowed for an impartial and public examination of the need for further investment. Admittedly, in economic regulation there are informational asymmetrics between the regulator and the utility, along with risks of "gold plating,” such as the over-engineering and over-generous employment practices identified

Wendy Stueck, "B.C. considers revising energy self-sufficiency goals,” The Globe and Mail (28 August 2011), online: The Globe and Mail <http://www.theglobeandmail.com/news/british-columbia/bcconsiders-revising-energy-self-sufficiency-goals/article2145060/>.

156 See e.g. Justine Hunter, "Clark’s Hydro policy threatens to collapse climate-change progress, scientist says,” The Globe and Mail (7 September 2011), online: The Globe and Mail <http://www.theglobeand mail.com/news/british-columbia/clarks-hydro-policy-threatens-to-collapse-climate-change-progressscientist-says/article558045/>.

157 Robert Matas, "Where are all the new B.C. mines," The Globe and Mail (29 September 2011), online: The Globe and Mail <http://theglobeandmail.com/news/british-columbia/where-are-all-the-new-bcmines/article1361228/>; Justine Hunter, "Clark's jobs plan needs huge power hike, BC Hydro says," The Globe and Mail (10 October 2011), online: The Globe and Mail <http://theglobeandmail.com/ news/british-columbia/clarsk-jobs-plan-needs-huge-power-hike-bc-hydro-says/article556665/>. Justine Hunter, "BC Hydro caught in crosshairs of Clark's populist push," The Globe and Mail (13 October 2011), online: The Globe and Mail <http://www.theglobeandmail.com/news/british-columbia/ bc-hydro-caught-in-crosshairs-of-clarks-populist-push/article558046> [Hunter, "BC Hydro caught”]. 
by the Review Panel. Notwithstanding such shortcomings, an independent regulatory agency could have provided an open forum in which to determine the need for unpopular, but necessary, rate increases. Too much politics, too soon, causes short-term concerns which overwhelm any serious analysis of longer-term considerations. Premier Clark's populist "family first" agenda was to have additional repercussions on relations between government and regulatory agencies.

Since 2003, when BC Ferry Services (BC Ferries) had been established as a publiclyowned corporation run on commercial lines, the Liberal government had refrained from intervening in the setting of fares by leaving it to the independent BC Ferries Commissioner (Commissioner), as provided for in Part 4 of the Coastal Ferry Act. ${ }^{159}$ The whole object of that legislation was to take ferry services "out of politics" and place them, as near as may be, into a commercial basis. This "hands off" approach broke down when the Commissioner gave preliminary approval to increase fares on Mainland to Vancouver Island routes by 4.15 percent, and increase other coastal routes by 8.23 percent. ${ }^{160}$ In response, an amendment to the Coastal Ferry Act was adopted, limiting increases on all routes to 4.15 percent, while provision was made to compensate BC Ferries for the denial of increases on the politically sensitive "thin" routes. ${ }^{161}$ Ministerial permission was now required for any route changes. As Les Leyne commented in the Times Colonist, "[a]ll those sermons from 2003 about the evils of political interference have gone by the wayside."162

As well as dealing with the controversial issue of differential rate increases, the amending legislation responded more broadly to the Commissioner's concern of reviewing his mandate and responsibilities, providing that the Commissioner review the Coastal Ferry Act itself and "recommend to the Minister of Transportation and Infrastructure such amendments to this Act as the commissioner considers will better enable the commissioner ... to balance the interests of ferry users with the financial sustainability needs of the ferry operators." ${ }^{\prime 63} \mathrm{His}$ report was submitted on 24 January 2012, and the government has indicated that its response will be informed by consultations and engagements with coastal communities. ${ }^{164}$ In the meantime, BC Ferries has reported significantly lower traffic levels and a deficit originally estimated at \$20 million, which later increased to \$35 million, with rising fuel costs and a drop in tourism blamed for a bleak financial picture. The corporation has indicated that it will be applying to the Minister to cut up to 400 off-peak sailings on major routes. ${ }^{165}$ The popular lightning rod for protest about a commercially-oriented ferry service proved to be the \$1 million annual salary and $\$ 317,000$ pension that the BC Ferries Board of Directors (using the

\section{SBC 2003, с 14}

160 Rob Shaw, “B.C. halves hike on smaller ferries,” Times Colonist (25 May 2011), online: Canada.com <http://www2.canada.com/victoriatimescolonist/news/story.html?id=eb24c1e8-28e1-4ead-86aa0cdeee9085f8>.

161 Bill 14, Coastal Ferry Amendment Act, 2011, 3rd Sess, 39th Leg, British Columbia, 2011.

162 Les Leyne, "Politicians grab helm at ferries again," Times Colonist (25 May 2011), online: Canada.com <http://www2.canada.com/victoriatimescolonist/news/comment/story.html?id=a9241099-da7a-41449c5e-a802453736fc>.

163 Coastal Ferry Act, supra note 159, s 53.1.

164 BC Ferry Commission, Review of the Coastal Ferry Act (24 January 2012), online: BC Ferry Commission <http://www.bcferrycommission.com/wp-content/uploads/2012/01/12-01-24-BCFC-CFARegulatory-Review-FINAL.pdf>.

165 Wendy Stueck, "BC Ferries proposes route cuts to stem losses,” The Globe and Mail (24 August 2011), online: The Globe and Mail <http://www.theglobeandmail.com/news/british-columbia/bc-ferriesproposes-route-cuts-to-stem-losses/article600885/>. 
private sector as a yardstick) had decided to pay their President and CEO, David Hahn. ${ }^{166}$ Declaring that “all the hard, really nasty stuff” had been wrapped up, Hahn took early retirement, a year and a half short of his ten-year contract. ${ }^{167}$ In defending Hahn's financial package in the face of a statement from Premier Clark that his pension was "way, way too big," ${ }^{168}$ Donald Hayes, Chair of the Board of Directors, praised his leadership since 2003 and added, "[e]veryone needs to recall the sad state of affairs that existed just eight years ago when BC Ferries was created as an independent entity.... BC Ferries was in a crisis state and the organization needed a complete overhaul by private-sector leaders with a track record of success." ${ }^{169}$ Be that as it may, Hahn's successor will only be entitled to a salary "not greater than the remuneration that provincial public sector employers in British Columbia provide to individuals who, in those organizations, perform similar services or hold similar positions to that executive of BCFS."170

In the case of BC Hydro, Premier Clark had managed to intercept an unacceptable increase before the BCUC made a binding decision, while, with respect to BC Ferries, she was able to override a preliminary decision by way of legislation. By contrast, the responsible Minister was able to scotch a new and unpopular rate structure proposed by the Insurance Corporation of British Columbia (ICBC) before it even reached its regulator, the BCUC. ICBC, a publicly-owned auto insurance corporation, had released details of a proposed new rate structure based largely on driving records. Under the new rate structure, it was estimated that one third of British Columbia drivers would end up paying higher vehicle insurance premiums, with the new revenue being used to provide discounts for those drivers who had not received tickets. The proposal was immediately denounced as mandating a rate increase for just one speeding ticket. ${ }^{171}$

Solicitor General Shirley Bond, the Minister responsible for ICBC, was scathing in her criticism of ICBC's president and CEO, Jon Schubert, for not consulting her in advance: “If you are going to talk about rates that impact literally thousands and thousands of drivers in British Columbia, you might want to sit down and have a conversation with the minister responsible." ${ }^{\prime 72}$ Even before she spoke to the press, ICBC had abandoned plans to submit a new rate structure to the BCUC. By catching the matter early on (but seemingly accidentally), the Minister was able to act by way of the government's ownership. As she explained:

Gary Mason, “NDP vows to poke a hole in B.C. Ferries CEO’s ballooning pension,” The Globe and Mail (12 July 2011), online: The Globe and Mail <http:/www.theglobeandmail.com/news/britishcolumbia/ndp-vows-to-poke-a-hole-in-bc-ferries-ceos-ballooning-pension/article625805/ ?service=mobile>; Robert Matas, "BC Ferries directors defend CEO pension,” The Globe and Mail (12 July 2011), online: The Globe and Mail <http://www.theglobeandmail.com/news/british-columbia/bcferries-directors-defend-ceo-pension/article586708/> [Matas, “Directors defend pension”]; Gary Mason, "Ferry corporation off course on pension move,” The Globe and Mail (13 July 2011), online: The Globe and Mail <http://www.theglobeandmail.com/news/british-columbia/ferry-corporation-off-course-withpension-move/article2095428/>.

Justine Hunter, "BC Ferries CEO takes smaller pension, bows out early,” The Globe and Mail (27 September 2011), online: The Globe and Mail <http://www.theglobeandmail.com/news/national/britishcolumbia/bc-politics/bc-ferries-ceo-takes-smaller-pension-bows-out-early/article2181737/>. Matas, "Directors defend pension,” supra note 166. Ibid.

Coastal Ferry Act, supra note 159, s 21.4(2)(ii).

Justine Hunter, “Liberals reject ICBC rate hike,” The Globe and Mail (16 May 2011), online: The Globe and Mail <http://www.theglobeandmail.com/news/british-columbia/liberals-reject-icbc-rate-hike/article $580022 />$.

Ibid. 
I haven't intervened in the actual rate decisions, those are things that still go before the BCUC. But let's be clear, government is the shareholder of this organization, and what I was most disappointed about was the fact that there was a complete lack of consultation, even a common briefing, about an issue that suddenly hit the public domain. ${ }^{173}$

In view of the flurry of contretemps involving relations between the government and regulators in British Columbia, it is important to notice that in the 3 October 2011 Speech from the Throne, ${ }^{174}$ the Clark government, after congratulating itself for reducing BC Hydro rates by half through taking a "hard look" at its operations, went on to promise more of the same: "The government will take a similar hard look at all Crown corporations, starting in January to ensure taxpayers and families are protected and the interests of all British Columbians are well served." 175 It remains to be seen how the boundaries between the government and its regulatory agencies will be shifted to accommodate the demands of populist politics.

\section{REgUlatory Structural REFORMS in Alberta?}

Turning to Alberta, I would ask you to recall that in 2007, the Board Governance Review Task Force (the Task Force) under the chairmanship of Neil McCrank, reported that there were almost 250 agencies, boards, and commissions in the province. ${ }^{176}$ Remarkably, about 50 percent of the Government of Alberta's annual operating expenditures were administered through this plethora of agencies, boards, and commissions. ${ }^{177}$ The Task Force's report called for the Legislature to establish a new governance framework and classification system, and to recognize that the legitimate need for agency freedom of action had to be reconciled with the equally legitimate need for government oversight and policy guidance, as well as improved internal governance.

The Task Force's At a Crossroads report was premised on ministerial accountability being at the core of constitutional government. Yet by their very nature, at least some agencies require considerable autonomy from government to perform their tasks. Nevertheless, the Task Force insisted that there must be a measure of accountability for all, as ultimately the government was responsible and answerable for the actions of its agencies. ${ }^{178}$

This concept of accountability meant that there could only be a strict, hierarchical delegation of authority by the Legislature to the Minister and then to the agency, with accountability flowing from the agency to the Minister and then to the Legislature. In effect, the Task Force adopted, from my perspective, an excessively rigid top-down, bottom-up model of authority and accountability, which threatened to isolate independent regulatory agencies as the "structural heretics" discussed earlier.

Ibid.

British Columbia, Legislative Assembly, Hansard, 39th Parl, 4th Sess No 1 (3 October 2011) at 7899 (Hon Steven L Point), online: Legislative Assembly of British Columbia <http://www.leg.bc.ca/hansard/ 39th4th/H1003pm-01.pdf>.

Ibid at 7900 .

Board Governance Secretariat, At a Crossroads: The Report of the Board Governance Review Task Force (Edmonton: Board Governance Secretariat, 2007) at 12, online: Alberta Treasury Board and Finance <http://www.treasuryboard.alberta.ca/docs/AGS/At_a_crossroads_-_screen.pdf $>$ [At $a$ Crossroads]. 
The Task Force favoured a new classification system which would recognize five types of agencies:

- $\quad$ regulatory/adjudicative;

- $\quad$ public trusts;

- $\quad$ corporate enterprises;

- $\quad$ service delivery; and,

- $\quad$ advisory. ${ }^{179}$

However, the Task Force urged that all these diverse agencies be brought under one piece of legislation ${ }^{180}$ — the proposed Alberta Public Agencies Governance Act. ${ }^{181}$ This seems to not fully take into account the very wide differences in the nature of appropriate accountability between, say, service delivery and regulatory/adjudicative agencies. The danger was that this approach would lead to a "one size fits all” solution, which is, as I will be suggesting in a moment, what I believe has happened.

While keen to see a single piece of legislation governing the relationship between public agencies and government, the Task Force did recognize that there might be need for "quasijudicial independence”182 in the decision-making of some agencies. In its 2008 overall acceptance of At a Crossroads, the government made a revealing concession in its Framework document: "Note that this Framework should not be construed so as to interfere with the principles of judicial independence and administrative law that are essential to the functioning of quasi-judicial agencies." ${ }^{183}$ A further implementation note added that "[a]djudicative agencies may wish to highlight how the agency-government relationship will respect the principle of judicial independence."184

What we now need to consider is whether these somewhat belated concerns for adjudicative autonomy were effectively implemented in the APAGA itself.

The APAGA received Royal Assent on 4 June 2009, but it has not yet been proclaimed into law. In the meantime, the Agency Governance Secretariat has begun carrying out a roundup of agencies, boards, and commissions, culling some and seeking to brand them all with accountability to their Ministers. Guidelines with respect to the review of adjudicative agencies, while recognizing that independence in decision-making is the cornerstone of an adjudicative agency's work and that review must not include any assessment of the appropriateness of the decisions made by such agencies, were nonetheless designed to probe whether there was effective governance respecting both the independence of adjudicative functions and ministerial accountability. ${ }^{185}$

Ibid at 17 .

Ibid at 12.

Supra note 131.

At a Crossroads, supra note 176 at 15 .

Agency Governance Secretariat, Public Agencies Governance Framework (Edmonton: Agency Governance Secretariat, 2008) at 7, online: Alberta Treasury Board and Finance <http://treasuryboard. alberta.ca/docs/AGS/GovernanceFrameworkwebversion.pdf> [emphasis in original]. Ibid at 16 .

Agency Governance Secretariat, Adjudicative Agency Review Guidelines (draft) (Edmonton: Agency Governance Secretariat, 2010) [on file with author]. 
The problem, as I see it, is that the APAGA is too all-embracing, and comes down so heavily on the side of ministerial accountability that it is simply inappropriate for independent regulatory and adjudicative bodies. Consider the preamble which reveals the premises on which the Act is based:

WHEREAS Ministers of the Crown are accountable to the public for the activities and performance of public agencies in their ministries;

WHEREAS public agencies are responsible for their activities and for the fulfilment of their mandates, and are accountable to their responsible Minister respecting their activities, successes and failures;

WHEREAS public agencies require varying degrees of authority to fulfil their mandates; and

WHEREAS clear communication and transparency are desirable with respect to the governance, mandates and activities of public agencies;

THEREFORE HER MAJESTY, by and with the advice and consent of the Legislative Assembly of Alberta, enacts as follows. ${ }^{186}$

Public agencies, which include independent regulatory agencies, are not seen as being entitled to autonomy but merely "varying degrees of authority to fulfill their mandates," and are subject to comprehensive accountability to their responsible Minister for their "activities, successes and failures.” The responsible Minister, as is further provided in the body of the Act, shall advise a public agency of any government policies applicable to it, or its activities or operations. ${ }^{187}$ As well, the Minister "may set policies that must be followed by the public agency in carrying out its powers, duties and functions." 188 Ironically, given the overall thrust of the legislation, it is then provided that no policy may be set in respect of a public agency's “adjudicative functions"; ${ }^{189}$ although what will be needed is authority to give general policy directions in respect of the future exercise of adjudicative functions. Nor is there to be any ministerial review power, which means that a Minister may be held accountable under the Act for a decision they cannot change. As well, there is no requirement for transmitting ministerial policy in a manner that is compatible with agency independence, such as that the policy must take the form of a regulation or involve consultation with the agency, or, heaven forbid, public consultation. Given the stark nature of the Act's provision that "the Minister may set policies that must be followed,” would a telephone call suffice? Or perhaps, a tweet!

There is a whole lot more that needs to be said about the APAGA, but let me make one final point: an independent regulatory agency should not be accountable to its responsible Minister, but should be answerable to its creator, the Legislature, through the Minister. A small point, but one of considerable symbolism.

The Agency Governance Secretariat website tells us, “[t]he Act has not been proclaimed as the Government would like departments and agencies to have more time to work with the 
Framework and experience the practical implications and benefits prior to proclamation.”190 I believe that it would be better to scrap the over-inclusive, "one size fits all” approach adopted in the APAGA, and set up separate and distinct accountability regimes for the classifications suggested by the Task Force — regulatory/adjudicative, public trusts, corporate enterprises, service delivery, and advisory. This would allow for sufficient recognition of uniqueness (a vital notion in administrative law) without abandoning the Task Force's commendable determination to get things under control.

\section{CONCLUSION}

When I started to think about what I was going to say, I looked back on my long interest in the nature of the relationship between governments and independent regulatory agencies which started with being imbedded for six months in the Canadian Transport Commission by the Law Reform Commission of Canada in the mid-1970s to learn what I could about regulation from the inside. A major section of the resulting study was concerned with government-commission relations. ${ }^{191}$ And I have been involved with this issue periodically ever since.

Initially I was quite depressed. In looking at current issues, they all seemed so, as my students would say, "same old, same old.” But then it dawned on me that this sense of "déjà vu all over again" was inevitable in that what is involved here in the periodic working out of the "Great Canadian Compromise" on regulatory independence and political control. The circumstances and technology involved might change, and there might be periodic swings from more to less political control and back again, but the Compromise would endure. We are never going to abandon independent regulatory agencies, nor will we give up on ultimate political control. We will insist on having our cake and eating it too, even if we choke on it occasionally. It will never be a question of whether there should be political control, only how it can be achieved without excessively compromising the integrity of the regulatory agencies.

I remain convinced that the Law Reform Commission of Canada, ${ }^{192}$ the Economic Council of Canada, ${ }^{193}$ and the Senate Committee ${ }^{194}$ were right in urging a shift in the focus of political control away from individual decisions to general policy. I was pleased that the much more recent, and much admired, Telecommunications Policy Research Panel, agreed with this approach. $^{195}$

Looking back, I see that the weakness in all these regulatory reform proposals has been that we, and by that I mean all who are interested in administrative law and regulation, have failed to educate our political masters as to the importance of protecting the independence and integrity of regulatory agencies. If we could ever do so, that would really be the cat's pajamas!

Agency Governance Secretariat Treasury Board, online: Government of Alberta <http://www.treasury board.alberta.ca/AgencyGovernanceSecretariat.cfm>.

HN Janisch, The Regulatory Process of the Canadian Transport Commission (Ottawa: Law Reform Commission of Canada, 1978) at 107.

Independent Administrative Agencies, supra note 59.

Reforming Regulation, supra note 60.

Janisch, “At Last!," supra note 55.

Final Report, 2006, supra note 63 at 9-18. 